Amasya İlahiyat Dergisi - Amasya Theology Journal

ISSN 2667-7326 | e-ISSN 2667-6710

Haziran / June 2021, 16: 267-299

\title{
İslam Fıkhında Ölünün Yaşayanlar Üzerindeki Haklanı
}

\author{
Mesut BAYAR \\ Dr. Öğr. Üyesi, Dicle Üniversitesi, İlahiyat Fakültesi, \\ İslam Hukuku Anabilim Dalı \\ Assistant Professor, Dicle University, Faculty of Theology, \\ Department of İslamic Law \\ Diyarbakır, Turkey \\ mesalem6@hotmail.com \\ orcid.org/0000-0003-0119-7792 \\ Makale Bilgisi / Article Information
}

Makale Türü / Article Types: Araştırma Makalesi / Research Article

Geliş Tarihi / Received: 11 Mart / March 2021

Kabul Tarihi / Accepted: 10 Mayıs / May 2021

Yayın Tarihi / Published: 30 Haziran / June 2021

Yayin Sezonu / Pub. Date Season: Haziran / June

Sayı / Issue: 16 Sayfa / Pages: 267-299

Atıf / Cite as: Bayar, Mesut. “İslam Fıkhında Ölünün Yaşayanlar Üzerindeki Haklar1 [The Rights of the Dead Over the Alives in Islamic Fiqh]". Amasya Illahiyat Dergisi-Amasya Theology Journal 16 (June 2021): 267-299.

https://doi.org/10.18498/amailad.895211.

İntihal / Plagiarism: Bu makale, en az iki hakem tarafından incelendi ve intihal içermediği teyit edildi. / This article has been reviewed by at least two referees and scanned via a plagiarism software.

Copyright @ Published by Amasya Üniversitesi, İlahiyat Fakültesi / Amasya University, Faculty of Theology, Amasya, 05100 Turkey. All rights reserved. https://dergipark.org.tr/amailad. 


\section{The Rights of the Dead Over the Alives in Islamic Fiqh}

\section{Abstract}

Death is a reality that will happen to every person. As long as the person is in this world, he has responsibilities and rights. With death, the responsibility of the person ends. But their rights continue for a certain period of time. These rights were explained in our article. The aim of the article is to determine the rights of the deceased on the living and to explain the jurisprudence rights in terms of fiqh. For, understanding the rights of the dead; are discussed in three parts. the rights to the deceased's estate, rights to the body of the deceased and the rights to the soul of the dead. The continuation of legal regulations to a person after death shows that man has never been neglected by his Lord. Because these rights for the dead are provided by Him. Nobody can take away this right. The existence of rights regarding the body of the dead shows the value given to man. As the living thing of man is valuable, his dead body is also valuable. For these reasons, it is haram to harm the body of the living like to harm the body of the dead. Practices such as performing the funeral prayer of the dead, shrouding, washing, and burial are signs of the spiritual value given to the body of the deceased. With death, the rights of the deceased pass from him responsibility to him estate after a certain period of time. The deceased has both financial rights and personal rights, and sometimes two rights together. Personal rights end with death and do not pass on to heirs, on the other hand, solely financial rights pass on to heirs. Unless the financial rights of the deceased are paid, his estate is not distributed to the heirs. The debts of Allah; under normal conditions, not fall. However, if a person is unable to do this as long as he lives, this debt is deducted by ransom, as in fasting. The possibility of this after death; there are different judgments on this subject according to worship and different opinions of jurists in details. After death, the soul leaves the corpse, and with the grip of the soul, its disposition on the body ends. When the savings of the soul in the body cease, the field of action also disappears. On the other hand, there are practices that the dead have no effect and those who live after him death do for his. The performance of these practices by the living can be regarded as a right for the soul of the dead. In our study, were explained the rights to the soul and the fiqh judgements of the issues believed to affect the soul. Accordingly, it is unanimously accepted as a right that the living pray for the souls of the dead and make forgiveness their sins.It is also accepted by the majority that the recited Quran will be donated to the souls. These jurisprudences constitute the most important evidence of the existence of 
M. BAYAR / The Rights of the Dead Over the Alives in Islamic Fiqh I 269 rights for the souls of the dead. There are new developments about the nature of death every day. The fact that death includes a process until the person who completes this worldly life is resurrected makes the subject important. In this respect, Muslims need to be informed about the consequences of death. Considering that there is also information pollution on this subject today, the necessity of bringing together our duties against the dead in a study emerges. It is thought that this study contributes to death issue within the framework of the deceased's rights. The article consists of three titles following the introduction. In the first title, the concepts of death and right, which constitute the basic concepts of the research, were explained in proportion to their relevance to the subject. General results of death were given under the second title. In the third title, the rights of the deceased over the living were classified as one of these results and the rights to the body, estate and soul of the deceased are mentioned in turn.

Keywords: Islamic Law, Death, Dead, Right, Corpse.

\section{Öz}

\section{İslam F1khında Ölünün Yaşayanlar Üzerindeki Haklanı}

Ölüm, her insanın başına gelecek olan bir gerçektir. Kişi bu dünyada olduğu sürece sorumluluklar yüklenmekte ve haklara sahip olmaktadır. Ölümle birlikte kişinin sorumluluğu bitmektedir. Fakat hakları belli bir süre devam etmektedir. Bu haklara literatürde ölünün hakları denilmektedir. Makalemizde söz konusu haklar açıklanmıştır. Makalenin amacı, ölünün yaşayanlar üzerinde haklarını tespit etmek ve bu hakların fıkıh açısından hükümlerini açılamaktır. Hükümlerin anlaşılabilmesi için ölünün hakları; ölünün terikesine yönelik haklar, ölünün bedenine yönelik haklar ve ölünün ruhuna yönelik haklar olmak üzere üç kısımda ele alınmıştır. Ölümden sonra da kişi ile ilgili hukuki düzenlemelerin devam etmesi insanın Rabbi tarafından hiçbir zaman ihmal edilmediğini göstermektedir. Çünkü ölü için haklar O'nun tarafından verilmiştir. Hiç kimsenin bu hakkı ortadan kaldırma yetkisi yoktur. Ölünün bedenine yönelik hakların var olması insana verilmiş olan değeri göstermektedir. İnsanın dirisine değer verildiği gibi ölüsüne de değer verilmiştir. Bu sebeplerle dirinin de ölünün de bedenine zarar vermek haram kılınmıştır. Ölünün cenaze namazının kılınması, kefenlenmesi, yıkanması ve gömülmesi gibi uygulamalar ölünün bedenine verilen manevi değerin diğer belirtileridir. Ölümle birlikte ölünün hakları belli bir süre sonra zimmetinden terikesine geçer. Ölünün sırf mali hakları ve sırf şahsi hakları olduğu gibi bazen de bu iki hakk beraber 
bulunmaktadır. Şahsa bağlı haklar ölümle sona ermekte ve mirasçılara intikal etmemektedir. Buna karşılık sırf mali hakları varislere intikal etmektedir. Bundan hareketle ölünün mali hakları ödenmeden terikesi varislere taksim edilmemektedir. Allah haklarına gelince; normal şartlarda Allah hakkı sakıt olmaz. Ancak kişi yaşadığı sürece bunu yapamayacak durumda ise oruçta olduğu gibi fidye vermek suretiyle bu borcu düşürme hakkına sahiptir. Öldükten sonra bunun imkânına gelince; bu konuda ibadete göre değişen hükümler ve fakihlerin detaylarda farklı görüşleri bulunmaktadır. Ölümden sonra ruh cesetten ayrilmakta, ruhun kabzedilmesi ile beden üzerindeki tasarrufu sona ermektedir. Ruhun bedendeki tasarrufu kesilince amel etme sahası da ortadan kalkmaktadır. Diğer yandan ölünün yaşarken üzerinde herhangi bir etkisinin olmadığı ve ölümünden sonra yaşayanların kendisi için yerine getirdikleri bazı ameller mevcuttur. Bu amellerin diriler tarafından ifası ölünün ruhu için bir hak olarak değerlendirilebilir. Çalışmamızda ruha yönelik haklar ile ruha etki edildiğine inanılan meselelerin de fıkhi hükümleri açılanmıştır. Buna göre dirilerin ölülerin ruhları için dua okumaları ve günahlarının bağışlanması için istiğfarda bulunmaları ittifakla bir hak olarak kabul edilmektedir. Okunan Kur'an'ın ölülerin ruhlarına bağışlanacağı da çoğunluk tarafından kabul edilmiştir. Bu hükümler ölünün ruhlarına yönelik hakların mevcut olduğunun en önemli delillerini oluşturmaktadır. Ölümün mahiyeti hakkında her geçen gün yeni gelişmeler meydana gelmektedir. Ölüm, bu dünya hayatını tamamlayan kişinin tekrar diriltileceği güne kadarki bir süreci içine alması, ölümlü olan insan için konuyu önemli hale getirmektedir. Bu açıdan Müslümanların ölümün sonuçları konusunda bilgi sahibi olmaları bir vecibedir. Günümüzde bu konuda bilgi kirliliğinin de mevcut olduğu düşünüldüğünde ölüye karşı vazifelerimizi bir çalışmada bir araya getirmenin gerekliliği ve önemi bariz bir şekilde ortaya çıkmaktadır. Bu çalışmayla ölünün hakları çerçevesinde ölüm konusuna katkıda bulunulduğu düşünülmektedir. Makale, girişi takip eden üç başlıktan oluşmaktadır. Birinci başlıkta, araştırmanın temel kavramlarını oluşturan ölüm ve hak kavramları konu ile ilgileri oranında açıklanmıştır. İkinci başlık altında ölümün genel olarak sonuçları verilmiştir. Üçüncü başlıkta ise bu sonuçlardan biri olarak ölünün yaşayanlar üzerindeki hakları tasnif edilmiş ve ölünün bedenine, terikesine ve ruhuna yönelik haklar sırayla zikredilmiştir.

Anahtar Kelimeler: İslam Hukuku, Ölüm, Ölü, Hak, Ceset. 


\section{Giriş}

İslam'a göre insanın yaşamı, dünya hayatıyla sınırlı değildir. İnsanın ruhunun ölmediğine, ölümle birlikte sadece bedenden ayrıldığına ve dünya hayatından sonra yeni bir hayatın başlayacağına inanılmaktadır. Bu gerçeğe binaen ölen bir insan ile ilgili birtakım haklar ortaya çıkmaktadır. Fıkıh eserlerinde ölünün hakları daha ziyade cenazenin teçhiz-teşyi işlemlerini, bu işlemlerden doğan masrafları ve ölünün borçlarının ödemesini ifade etmek için kullanılmaktadır. ${ }^{1} \mathrm{Bu}$ sebeple ölünün hakları denildiğinde ölünün bedenine ve terikesine yönelik haklar öne çıkmaktadır. Ancak İzz. b. Abdüsselâm (öl. 660/1262) yukarıda zikredilenlere ek olarak ölüye dua etme ve onun için istiğfarda bulunma gibi durumları da ölünün yaşayanlar üzerindeki haklarına örnek olarak vermiştir. ${ }^{2}$ Ulaştığımız eserlerden Muhammed Hasen Ebû Yahyâ da Hukûku'l-meyyit ve Ahkâmuh fi'l-İslâm adlı eserinde ölünün haklarını açıklarken ölüye istiğfarda bulunma gibi manevi hakları da çalışmasına dâhil etmiştir. ${ }^{3} \mathrm{Bu}$ iki eserde verilen bilgilerden ölünün bedenine, terikesine ve ruhuna yönelik üç hak türünün mevcut olduğu anlaşılmaktadır. Bundan hareketle ölünün haklarının; bedenine yönelik haklar, terikesine yönelik haklar ve ruhuna yönelik haklar şeklinde tasnif edilmesi tarafımızdan uygun görülmüştür.

1 Ölünün hakları kavramının cenazeye katılma, teçhiz ve teşyi işlemlerin için kullanılmasına örnek olarak bk. Ebû Bekr Muhammed b. Abdillâh b. Muhammed elMeâfirî, el-Mesâlik fí şerhịi Muvatțai Mâlik, thk. Muhammed b. el-Süleymânî vd. (y.y: Dârü'l-Arabi'l-İslâmî, 1428/2007), 3/505; Ebü'l-Velîd Muhammed b. Ahmed b. Muhammed el-Kurtubî, Bidâyetü'l-müctehid ve nihâyetü'l-mukteșıd (Kahire: Dârü'lHadîs, 1425/2004), 1/238; Vehbe b. Mustafa ez-Zuhaylî, el-Fıkhü'l-İslâmî ve edilletuh (Dımaşk: Dâru'l-Fikr, 1405/1985), 2/457.

2 Kendisi ölü haklarını kul hakkının bir parçası olarak zikrederek kul haklarını hayattaki kul hakları ve öldükten sonraki kul hakları diye ikiye ayırmaktadır. Ardından ölünün haklarını teçhiz, teşyi, tedfin, onlara dua ve istiğfarda bulunma, kabirlerinin ziyaret edilmesi şeklinde sıralamaktadır. Bk. Ebû Muhammed İzzüddîn Abdülazîz b. Abdüsselâm, Kavâidü'l-ahkâm fì masâlihi'l-enâm, thk. Tâhâ Abdurraûf Sa 'd (Kahire: Mektebetü'l-Külliyyati'l-Ezheriyye, 1414/1994), 1/166-167.

3 Muhammed Hasen Ebû Yahyâ, Hukûku'l-meyyit ve ahkâmuh fi'l-İslâm (Umman: Dârü Yafa'l-ilmiyye, 1431/2010), 423. 
Konu ile ilgili diğer araştırmalarda ise ölünün terikesine ${ }^{4}$ veya bedenine yönelik haklar bir araya getirilmiştir. Ölümün terike haklarına etkisi konusunda Murat Tala'nın Ölümün Özel Haklara Etkisi ile Hüseyin Esen'in İslam Hukukunda Ölümün Mâlî Hak ve Borçlara Etkisi adlı çalışmaları bulunmaktadır. Ölünün bedenine yönelik ise Rukiye Es`ad Sâlih Arâr'ın Ahkâmü't-tasarruf bi'l- cüsse fi'l-Fıkhı'l-İslâmî adlı Arapça çalışmasına ulaşılmıştır. Ölünün ruhuna yönelik haklarını tek bir başlık altında işleyen çalışmalara ise ulaşılmamıştır.

Makalenin amacı, ölünün yaşayanlar üzerinde haklarını tespit etmek ve bu hakların fıkıh açısından hükümlerini açıklamaktır. Araştırmanın yöntemi, ölünün haklarını bedenine, terikesine ve ruhuna yönelik haklar olarak tasnif edip ölünün yaşayanlar üzerindeki haklarına genel bir bakış açısını sağlamaya dayanmaktadır. Araştırmanın problemi, ölünün ne gibi haklarının bulunduğunu ortaya çıkarmak ve öldükten sonra dirilerin kendilerine yönelik yapacakları amellerin fıkhî hükmünü tespit etmektir. Araştırmanın hipotezi, fıkhî hükümleri ele alırken bir bütünlük içerisinde değerlendirmek gerektiğidir. Makalenin temel problemi ve hipotezi doğrultusunda, ölülerin terikelerine ve bedenlerine yönelik hakların yanında ruhlarına yönelik hakların da mevcut olduğu, yaşayanlar tarafından ölülerin ruhlarına yönelik uygulamaların ise bazı şartlar dâhilinde caiz olduğu sonucuna ulaşılmıştır. Çalışmamızda üç hak türü dört mezhebin mutemed eserleri ışığında değerlendirilmiştir. Gerekli görülen yerlerde çağdaş eserlere de atıfta bulunulmuştur.

Makale, girişi takip eden üç başlıktan oluşmaktadır. Birinci başlıkta, araştırmanın temel kavramları olan ölüm ve hak kavramları konu ile ilgileri oranında açıklanacaktır. İkinci başlık altında ölümün genel olarak sonuçları verilecektir. Üçüncü bölümde ise bu sonuçlardan biri olarak ölünün yaşayanlar üzerindeki hakları tasnif edilecek ve ardından bedenine, terikesine ve ruhuna yönelik haklar sırayla zikredilecektir.

4 Çalışmamızda terike kavramı, cumhurun bakış açısıyla hem malî hem de malî olmayan hakları kapsayacak şekilde kullanılmıştır. Terikenin kapsamı, yeri geldiğinde mezheplerin farklı görüşleri ışığında açıklanacaktır. 
M. BAYAR / The Rights of the Dead Over the Alives in Islamic Fiqh I 273

\section{Araştırmanın Kavramları}

\section{1. Ölüm}

\subsubsection{Tanımı}

Ölüm, kelimesinin Arapça karşılığı mevt olup bir şeyin gücünün gitmesi ve yaşamın zıddı anlamına gelmektedir. Ölüm halinde insan ve diğer canlılardaki can gücü gittiğinden bu duruma mevt denilmiştir. ${ }^{5}$ Fakihler tarafından ölüm, ruhun bedenden ayrilmasi ${ }^{6}$ ve beden üzerindeki tasarrufunun kesilmesi olarak tarif edilmiştir. ${ }^{7}$ Buna göre bedenin yükümlülüğü ruha bağlıdır. Ruhun bedenden ayrılması ile tasarrufu bittiğinden bedenin de ehliyeti sona ermektedir.

F1kıh açısından bir insanın ölmüş sayılması bir süreliğine belli olmadığından ölüm için ruhun bedenden çıktığını gösteren alametler beden üzerindeki değişikliklerle ifade edilmektedir. Fakihlere göre bedeninin gevşemesi, burnun eğilmesi, şakakların sarkması, yüzün uzaması, derinin sarkması ve benzeri ölüm belirtileri bulunmaktadır. ${ }^{8}$

\subsection{2. Çeşitleri}

Kişinin ölümünün bir gerçeklik ve bir eyleme dönüştüğü, kişinin bedeninin ruhsuz bir vücuda dönüştüğü fiziksel ölüme gerçek ölüm, gerçekte yaşıyor olsa bile mahkemenin bir kişinin ölü olduğuna

5 Ebu'l-Hüseyn Ahmed b. Fâris b. Zekeriyyâ er-Râzî, Mu 'cemü makâyisi'l-luğa, thk. Muhammed Abdüsselâm Hârûn (Beyrut: Dârü'l-Fikr, 1399/1979), "mevt", 5/283.

6 Ebû Zekeriyyâ Muhyiddîn Yahyâ b. Şeref en-Nevevî, el-Mecmû Şerhü'l-Mühezzeb, thk. Muhammed Necib el-Mutî'î (Cidde: Mektebetü'l-İrşad, ts.), 5/96.

7 Ebû Hâmid Muhammed b. Muhammed el-Gazzâlî, İhyâu ulûmi'd-dîn (Beyrut: Dârü'lMa'rife, ts.), 4/493-494.

8 Ebü'l-Kâsım Abdulkerîm b. Muhammed er-Râfi'î, el-Azîz Şerhu'l-Vecîz, thk. Adil Ahmed Abdülmevcûd vd. (Beyrut: Dârü'l-Kütübi'l-i̇lmiyye, 1417/1997), 2/395; Ebû Muhammed Muvafakuddîn Abdullâh b. Ahmed b. Muhammed b. Kudâme, el-Muğn̂̂ (Kahire: Mektebetü'1-Kâhire, 1388/1968), 2/337. 
hükmetmesine hükmî ölüm, ${ }^{9}$ annesine karşı işlenen cinayet sonucu ölü olarak doğan ceninin ölümüne ise takdiri ölüm denir. ${ }^{10}$

Gerçek ölüm de somatik ve klinik ölüm olmak üzere ikiye ayrılır. Çağdaş hekimlere göre somatik ölüm temel vücut fonksiyonları olarak kabul edilen merkezi sinir sistemi, solunum ve dolaşım fonksiyonlarının dönüşsüz kaybıdır. Somatik ölümle birlikte, özellikle beyin sapındaki solunum ve dolaşım merkezinin devre dişı kalması sonucu süreç kaçınılmaz olarak tüm organ ve dokuların canlılık durumunu yitirmesi ile sonuçlanmaktadır. Buna da "hücresel ölüm" (biyolojik ölüm) denmektedir. ${ }^{11}$ Günümüzde bu iki ölüm türüne beyin ölümü de eklenmekte ve beyin ölümüyle ölümün gerçekleştiği genel olarak kabul edilmektedir. Bununla birlikte hangi ölüm türünün fikhen geçerli olduğu yönündeki tartışmalar devam etmektedir. Beyin ölümünün değil de kalbin durması gerektiği görüşünde olanlar da vardır. Tezinde konuya değinen Özdemir, kalp ölümünü esas alan âlimlerin bir kısmının ismini zikretmektedir. ${ }^{12}$ Ölümün tanısının yapılması ve zamanının tespiti önem arz etmektedir. Çünkü ölüye ait hakların intikali buna göre gerçekleşecektir. ${ }^{13}$

\subsection{Hak}

\subsubsection{Tanımı}

Hak, sözlükte, gerçek, sabit, batılın zıddı ve inkâr edilmesi mümkün olmayan sabite gibi anlamlara gelmektedir. Bu sebeple Allah

9 Hanefîler'e göre hakkında öldürülme kararı çıkmış olan ve düşman ülkeye sığınmış olan mürted ile Mâlikîlere göre mefkûd bazı şartlar dâhilinde hâkimin karar vermesinden sonra hükmen ölü olarak kabul edilmektedir. Bkz Ebû Bekr Şemsü'leimme Muhammed b. Ebî Sehl Ahmed es-Serahsî, el-Mebsût (Beyrut: Dârü'l-Ma'rife, ts.), 10/103; Ebu'l-Abbâs Şihâbuddîn Ahmed b. İdrîs el-Karâfî, ez-Zahîre, thk. Muhammed Hacî vd. (Beyrut: Dârü'l-Garbi'l-İslâmî, 1415/1994), 13/23.

10 Hüseyin Esen, "Ölüm”, Türkiye Diyanet Vakfi İslâm Ansiklopedisi (İstanbul: TDV Yayınları, 2007), 34/39.

11 Konuyla ilgili detaylı bilgi için bk. Sermet Koç - Muhammed Can, "Ölüm Kavramı ve Ölüm Muayenesi", Klinik Değişim 22/Özel Sayı (2009), 11.

12 Bk. Merve Özdemir, İslam Hukukuna Göre Beden Üzerinde Tasarruf ve Organ Nakli (Sakarya: Sakarya Üniversitesi, Sosyal Bilimler Enstitüsü, Doktora Tezi, 2017), 221.

13 Murat Tala, Ölümün Özel Haklara Etkisi (Konya: Selçuk Üniversitesi, Sosyal Bilimler Enstitüsü, Yüksek Lisans Tezi, 2006), 20. 
Teâlâ'ya Hakk denilmektedir. ${ }^{14}$ Terim olarak ise hakkın ele alındığı alan ile ilgili tanımlar yapılmış olduğundan hakkı tüm yönleriyle ele alan tanımlar bulunmamaktadır. Mustafâ Ahmed ez-Zerkâ, tüm tarifleri içine alan bir hak tanımına rastlamadığını belirtikten sonra tarifini "hukuk düzeninin kendisiyle bir hâkimiyet ve sorumluluk öngördüğü bir şey" olarak açıklamıştır. ${ }^{15}$

\subsubsection{Unsurları ve Çeşitleri}

Hakkın unsurları konusunda çağdaş fakihler arasında değişik görüşler bulunmaktadır. Vehbe Zuhaylî’nin görüşü hak sahibi ve hakkın konusu olmak üzere iki unsurunun bulunduğu yönündedir. ${ }^{16}$ Ali Bardakoğlu ise Diyanet İslam Ansiklopedisi "hak" maddesini ele alırken hak sahibi, hak borçlusu, hakkın konusu ve meşruiyeti olmak üzere dört maddeyi zikretmiştir. ${ }^{17}$

Hak kavramının kapsamının geniş olması çeşitlerini bir çatı altında toplamayı zorlaştırmaktadır. Bu sebeple tasnifler, hak sahibi veya hakkın konusu gibi hakkın unsurlarına göre yapılmaktadır. Hakkın sahibi açısından sırf Allah hakkı, sırf kul hakkı ve müşterek haklar olmak üzere üç tür haktan bahsedilmektedir. Diğer bir ayrım ise hakkın konusu ile ilgilidir. Bu ayrımda ise hakkın şahıslara mı yoksa bir nesneye mi yönelik olduğu veya malî bir özelliğinin bulunup bulunmadığına bakılmaktadır. Haklar, kişiye yönelik ise ister malî bir özelliği olsun ister olmasın buna şahsî haklar denir. Nesneye yönelik haklara ise aynî hak denilmekte ve kişinin bu nesne(ayn) üzerindeki hâkimiyet ve otoritesinin derecesine göre bir taksimat yapılmaktadır. ${ }^{18}$

\section{2. Ölümün Fıkhî Sonuçları}

Ölümün biri ölü açısından diğeri yaşayanlar açısından olmak üzere iki sonucu vardır. Ölen kişi açısından da biri dünyevî, diğeri uhrevî olmak üzere iki sonucu vardır. Dünyevî sonucu hukukî kişiliğin

14 Ahmed b. Muhammed b. Alî el-Feyyûmî, el-Mısbahu'l-münîr (Beyrut: Mektebetü Lübnan, 1987), "hakk", 55.

15 Mustafâ Ahmed ez-Zerkâ, el-Medhal ilâ nazariyyeti'l-iltizâmi'amme fi'l-fikhı'l-i̇slâmî (Dımaşk: Darü'l-Kalem, 1420/1999), 19.

16 Zuhaylî, el-Fıkhü'l-İslâmî, 4/10.

17 Ali Bardakoğlu, "Hak", Türkiye Diyanet Vakfi İslâm Ansiklopedisi (İstanbul: TDV Yayınları, 1997), 15/141.

18 Hakkın çeşitleri ile ilgi bk. Bardakoğlu, "Hak” 15/142-146. 
(ehliyetinin) sona ermesi ve zimmetin zayıflamasıdır. Buna göre ölüm, hem vucûb hem de eda ehliyetini ortadan kaldırmaktadır. Ancak Hanefîler; kişinin sağlığında başlayan ve ölümü sonrasında sonuçlanan teçhiz, tekfin ve tedfin gibi fiilleri zimmet ile ilişkili olduğundan ölüm sonrasında da vücûb ehliyetinin belli bir dönem devam ettiğinin delili olarak kabul etmektedir. ${ }^{19}$

Aynı şekilde ölümle birlikte zimmetin keskin ve ani bir şekilde sonlandırılması bazı hakların kaybına yol açabileceğinden zimmetin kural olarak keskin bir şekilde ve aniden sonlanmadığ benimsenmiştir. Bundan dolayı klasik literatürde zimmetin ölüm sonrasında terekeye dair haklar tasfiye edilene kadar devam ettiği veya zayıfladığı yönünde ifadelere rastlansa da ağırlıklı görüş zimmetin ölümle "harap olduğu", istisnaî bazı hak ve borçlara ehliyet hariç, hukukî anlamda bu zimmetin davaya konu edilerek zimmete yönelik bir alacak hakkı iddiasında bulunulamayacağı yönündedir. ${ }^{20}$

Uhrevî sonucu ise ölünün amellerinin kesilmesidir. Tüm amellerin kayıt altına alındığı bir defter vardır ve kıyamet gününde kişiye verilecektir. ${ }^{21}$ Âyetlerde ve hadislerde belirtildiği üzere ölümden sonra amelin değerlendirilmesi bitmektedir. Âyette ölümü gelen bir kişinin salih amel temenni edeceği ancak buna izin verilmeyeceği belirtilir. ${ }^{22}$ Bir hadiste belirtildiği gibi ölümle birlikte insanın ameli kesilir. Ancak kendisinin hayatta iken vasita olduğu ameller devam eder. Bunlar hayatında iken sebep olduğu salih ameller olup sadaka-1 cariye salih evlat ve faydalanılan ilim gibi şeylerdir. ${ }^{23}$ Başka bir hadise göre de iyi bir çığır açanın iyilikleri veya kötü bir çığır açanın kötülükleri devamlı yazılır. ${ }^{24}$

Ölümün yaşayanlar üzerinde de bazı sonuçları vardır. Buna göre ölüm, ölünün yakınları başta olmak üzere yaşayanlara bazı

19 Serahsî, el-Mebsût, 29/182.

20 Eyyüp Said Kaya - Hasan Hacak, "Zimmet", Türkiye Diyanet Vakfı İslâm Ansiklopedisi (İstanbul: TDV Yayınları, 2013), 44/426.

21 el-İsrâ 17/13-14.

22 el-Mü'minûn /99-100.

23 Ebû Abdurrahmân Ahmed b. Şuayb en-Nesâî, es-Sünen 'ü'ș-șuğrâ, thk. Abdülfettâh Ebû Gudde (Haleb: Mektebü'l-Matbû'âti'l-İslâmiyye, 1406/1986), "Vesâyâ", 30 (No. 3651).

24 Ebu'l-Hüseyn Müslim b. Haccâc el-Kuşeyrî, Sahîhu Müslim, thk. Muhammed Fuâd Abdülbâkî (Beyrut: Dârü İhyâi't-Türâsi'l-Arabî, ts.) "Zekât", 20. 
M. BAYAR / The Rights of the Dead Over the Alives in Islamic Fiqh I 277

sorumluluklar yüklemektedir. Bu sorumlulukları yerine getirmek ölülerin onlar üzerindeki hakkıdır.

\section{3. Ölünün Yaşayanlar Üzerindeki Hakları}

Ölünün diriler üzerindeki hakları hakkın unsurları açısından değerlendirildiğinde ölü hak sahibi, diriler ise hak borçlusu olmaktadır. Ölünün diriler üzerindeki bu hakkı, hakkın sahipliği açısından ise kul hakkı kapsamına girmektedir. Mezkûr kul hakkının sırf kul hakkı mı olduğu yoksa Allah hakkı ile beraber müşterek bir hak mı olduğu önem kazanmaktadır. İzz b. Abdüsselâm, ölünün diriler üzerindeki hakların kul haklarının bir kısmını oluşturduğunu ancak içinde Allah hakkı da bulunduğundan yıkanmamayı, defnedilmemeyi ve üzerinde namaz kılınmamasını isteyen ölünün vasiyetinin bu sebeple yerine getirilmeyeceğini belirtmektedir. ${ }^{25}$

Ölünün yaşayanlar üzerindeki haklarını yakın akrabaları üzerindeki hakları ve tüm Müslümanlar üzerindeki hakları olmak üzere ikili bir ayrıma tabi tutmak mümkündür. Konumuz tüm Müslümanlar üzerindeki hakları ise de yakın akrabaları üzerindeki haklarından bahsetmek yerinde olacaktır.

Ölümle birlikte nikâh akdi sona ermektedir. Bu da ölünün hanımı için ölüm iddetini doğurmaktadır. Ölen erkeğin hanımı üzerindeki hakkı hanımının 4 ay 10 gün ölüm iddetini beklemesidir. ${ }^{26}$

Ölünün birtakım terike hakları bazı şartlar dâhilinde varislerine geçmektedir. Varisler de akrabalarından oluşmaktadır. Akrabaları olmadığında hakları başkalarına intikal etmektedir. Nitekim ölüm, hakkın intikal sebeplerinden biri olarak gösterilmektedir. ${ }^{27}$ Ancak ölünün zimmetinde olan borçlar ödendikten sonra bu hak ortaya çıkmaktadır.

Ölünün akrabaları üzerindeki haklarından biri de ölümünün onlar tarafından duyurulmasıdır. Çünkü ölünün öldüğünün duyurulması, bedenine yönelik hakların yerine getirilmesini sağlayacaktır. ${ }^{28}$

Ölümün, yaşayan Müslümanların geneli üzerindeki doğurduğu haklar da bulunmaktadır. Bunlardan biri cenazesinde bulunma hakkıdır. Nitekim Hz. Peygamber (s.a.v) Müslüman'ın Müslüman üzerindeki

\footnotetext{
25 İzzüddîn b. Abdüsselâm, Kavâidü'l-ahkâm, 1/166.

26 el-Bakara 2/234.

27 Zuhaylî, el-Fıkhü'l-İslâmî, 4/39; Bardakoğlu, “Hak”, 15/149-150.

28 Nevevî, el-Mecmû'; 5/216.
} 
haklarından bahsederken biri öldüğünde geride kalanların ölünün cenazesine katılmaların ${ }^{29}$ bu haklardan biri olarak zikretmiştir. Şimdi bunlar açıklanacaktır.

\section{1. Ölünün Bedenine Yönelik Haklar}

Hak konusunun ele alındığ 1 çağdaş eserlerde genel anlamda beden haklarından bahsedilmemektedir. Ancak Hasan Hacak hak kavramının gelişimi ile ilgili çalışmasında bedenî hak kavramının nadir de olsa kullanıldığını belirttikten sonra mali haklar-bedeni haklar şeklinde bir tasnif yapmıştır. ${ }^{30}$ Bedeni hakların da olduğu kabulü çerçevesinde ölünün bedenine yönelik hak, insan bedenine yönelik hakkın bir parçasıdır. Çünkü insanın bedeni muhteremdir. Ölü veya diri olması arasında fark yoktur. Ölünün bedenine yönelik haklar, teçhiz öncesi haklar, teçhiz hakları ve bedeni üzerinde operasyon yapılmaması hakkı olmak üzere üç kısımda incelenecektir.

\subsubsection{Cenazenin Teçhizine Başlanmadan Önceki Hakları}

F1kıh kitaplarında her şeyden önce ölünün gözlerinin yumulmasına değinilmektedir. Ölünün başına gelen ilk alamet, gözün ruhun arından bakakalmasıdır. Hz. Peygamber (s. a. v): "Ruh kabzedilince göz ona tabi olur (onu izler)" 31 buyurmaktadır. Kendileri Ebu Seleme'nin vefatında bunu belirtmiş ve onun gözlerini kapatmıştır. Bu konuda fakihlerin görüş birliği vardır. ${ }^{32}$

Ardından ölünün erkek olduğunda sakalının sıkılması ve eklemlerinin yumuşatılması uygulaması tavsiye edilmektedir. Ruh bedenden ayrıldıktan sonra bir süre bedende 1 sı bırakır. $O$ süreçte eklemler sertleşmediğinden rahat yumuşatılabilmektedir. Aksi takdirde bu artık mümkün olmaz. ${ }^{33}$

29 Ebû Abdillâh Muhammed b. İsmâîl el-Buhârî, el-Câmi 'u'ṣ-șahîh, thk. Muhammed Züheyr b. Nasr (b.y.: Dârü Tavki'n-Necât, 1422/2001), “Cenâiz”, 2 (No. 1240).

30 Hasan Hacak, İslam Hukukunun Klasik Kaynaklarında Hak Kavramının Analizi (İstanbul: Marmara Üniversitesi, Sosyal Bilimler Enstitüsü, Doktora Tezi, 2000), 120.

31 Müslim, “Cenâiz", 7 (920).

32 Alâuddîn b. Mes'ûd el-Kâsânî, Bedâi 'u's-sanâi fî tertîbi'ş-şerâi (Beyrut: Dârü'lKütübi'l-İlmiyye, 1406/1986), 1/299; Muhammed b. Abdullâh el-Haraşî, Şerhu Muhtasari Halîl (Beyrut: Dârü'l-Fikr, ts.), 2/122; Şemsüddîn Muhammed b. Ahmed elHatîb eş-Şirbînî, Muğni'l-muhtâc ilâ ma'rifeti me ânî elfâzi'l-Minhâc (Beyrut: Dârü'lKütübi'l-İlmiyye, 1415/1994), 2/331; İbn Kudâme, el-Mŭ̆nĥ, 2/336.

33 Haraşî, Şerhu Muhtasari Halîl, 2/122. 
M. BAYAR / The Rights of the Dead Over the Alives in Islamic Fiqh I 279

Ölünün kıbleye döndürülmesinin ve bunun da mümkün olduğu takdirde sağ tarafiyla yapılmasının müstehap olduğu konusunda da fakihler görüş birliği içindedir. Çünkü kıble, yönlerin en şereflisidir. Sadece bu kıble yönünün yol ve yöntemi konusunda farklı görüşler bulunmaktadir. ${ }^{34}$

\subsection{2. Ölünün Teçhizi}

Teçhiz, sözlükte bir konuda acele etmek, bir şeyi hazırlamak ve yolcuyu donatmak gibi anlamlara gelmektedir. ${ }^{35} \mathrm{~F}$ khî bir terim olarak ise ölünün yıkanması, kefenlenmesi, üzerine namaz kılınması, taşınması ve defnedilmesi gibi işlemlerden oluşmaktadır. ${ }^{36}$ Ölü, ahiret yolcusu hükmünde olduğundan defne kadar devam eden uygulamalara teçhiz denilmiştir. ${ }^{37}$

Teçhiz sürecinin bir an önce başlatılması önemlidir. Çünkü ölünün kokması ve insanların bundan rahatsızlık duymaları mümkündür. Ancak önce ölünün teçhizine mi yoksa borçlarının ödenmesinden mı başlanması gerektiği konusu doktrinde tartışmalıdır. Bununla ilgili fakihlerin görüşlerine ölünün terikesine yönelik haklar kısmında değinilecektir.

\subsubsection{Yikanmasi}

Ölüyü yıkamanın diriler üzerinde bir hak olduğu konusunda fakihlerin görüş birliği vardır. Ancak farz olup olmadığı konusunda ihtilaf bulunmaktadır. Âlimlerin çoğunluğuna göre ölünün yıkanması farz-1 kifâyedir. ${ }^{38}$ Ayrıca farz olan bir defa yıkamadır, üç defa yıkama sünnettir. ${ }^{39}$ Bazı Mâlikîler'e, ölüyü yıkamanın sünnet olduğu şeklinde bir görüş nispet edilmektedir. ${ }^{40}$

Ölüyü yıkamada niyet çoğunluğa göre gerekmez. Sadece Şâfiî ve Hanefîler'den bir görüş niyeti şart koşmaktadır. Cumhura göre kâfir bile

34 Zuhaylî, el-Fıkhü'l-íslâmî, 2/457.

35 Feyyûmî, el-Misbahu'l-münîr,"cehz", 44.

36 Ebû Habîb S’adî, el-Kâmûsu'l-fikhî (Dımaşk: Dârü'l-Fikr, 1408/1988), "meyyit", 343.

37 Muhammed Umeym el-İhsan el-Müceddidî b. Abdülmenan el-Bereketî, et-Ta'rîfâtü'lfıkhiyye (Beyrut: Dârü'l-Kütübi'l-İlmiyye, 1424/2003), "techîz", 52.

38 Serahsî, el-Mebsût, 30/263; Haraşî, Şerhu Muhtasari Halîl, 2/113; Ebû Zekeriyyâ Muhyiddîn Yahyâ b. Şeref en-Nevevî, Ravdatü't-tâlibîn umdetü'l-müftîn, thk. Züheyr eşŞâvîş (Beyrut: el-Mektebetü'l-İslâmî, 1412/1991), 2/98; Mansûr b. Yûnus el-Buhûtî, Keşşâfü'l-kına`an metni'l-ìkna` (Beyrut: Dârü'l-Kütübi'l-İlmiyye, ts.), 2/85.

39 Nevevî, Ravdatü't-tâlibîn, 2/101; Kâsânî, Bedâi u's-sanâi', 1/301.

40 Haraşî, Şerhu Muhtasari Halîl, 2/113. 
olsa ölü necis değildir. Hadesten dolayı yıkanmaktadır ${ }^{41}$ Hangi niyetle olursa olsun ölü yıkamada kullanılan suyun da diğer temizlemelerde olduğu gibi tahûr (temizleyici) olması gerekir.

Öncelik hem cinslerin birbirlerini yıkamalarıdır. Erkeği erkek, kadını kadın yıkar. Bu konuda fakihlerin görüş birliği vardır. ${ }^{42}$ Tertip konusunda ise mezheplerin değişik görüşleri vardır. Cumhura göre eşler birbirlerini yıkayabilir. ${ }^{43}$ Hanefîler'e göre ise arada ölümle beraber nikâh bağ 1 kalmadığ için yıkayamazlar. Ancak kadın, riddet veya talak gibi ayrılık sebepleri olan iddetlerden değil de sırf ölüm iddeti bekliyorsa kocasını yıkayabilir. ${ }^{44}$ Bir kadın ölür ve onu yıkayacak hemcinsi ve akrabaları yoksa cumhura göre teyemmümü yapmakla yetinilir ${ }^{45}$ ancak bazı Şâfiîler'e göre ölü sarılmış bir halde olur ve gasil de gözleri kapalı bir şekilde ölüyü yıkar. ${ }^{46}$

Kimlerin yıkanamayacağı konusunda mezheplerin farklı bakış açıları vardır. Tüm mezhepler şehidin yıkanmayacağı konusunda görüş birliği içindedir. ${ }^{47}$ Salgın hastalıklardan ölenler gibi uhrevi şehid ${ }^{48}$

41 Burhânüddîn Mahmûd b. Ahmed b. Abdilazîz el-Buhârî, el-Muhîțï'l-Burhânî fi'lfikhi'n-Nu 'mânî, thk. Abdülkerîm Sâmî el-Cündî (Beyrut: Dârü'l-Kütübi'l-İlmiyye, 1424/2004), 2/153; Ebû Abdillâh Muhammed b. Ahmed b. Muhammed İlîş Minehü'lcelîl Şerhü Muhtasari Halil (Beyrut: Dâru'l-fikr, 1409/1989).1/478.

42 Ebû Bekr Alâüddîn Muhammed b. Ahmed b. Ebî Ahmed es-Semerkandî, Tuhfetü'lfukahâ (Beyrut: Dârü'1-Kütübi'l-İlmiyye, 1414/1994), 241.

43 İlîş, Minehü'l-celîl, 1/478.

44 Semerkandî, Tuhfetü'l-fukahâ, 241.

45 Buhârî, el-Muhîțï'l-Burhânî, 2/155; Ilîş, Minehü'l-celîl, 2/212; Nevevî, Ravdatü't-tâlibîn, 2/105; İbn Kudâme, el-Muğnî, 2/394.

46 Ebû Muhammed Muhyissünne el-Hüseyn b. Mes'ûd b. Muhammed el-Ferrâ' elBegavî, et-Tehzîb, thk. Adil Ahmed Abdülmevcûd vd. (Beyrut: Dârü'l-Kütübi'lİlmiyye, 1418/1997), 2/416.

47 Serahsî, el-Mebsût, 2/49; Tâcüddîn Behrâm b. Abdillâh b. Abdilazîz ed-Demîrî; Tahbîru'l-Muhtasar, thk. Ahmed b. Abdilkerîm Necîb vd. (Saraybosna: Merkezu Necibuveyh, 1434/2013), 1/611; Nevevî, Ravdatü't-tâlibîn, 2/118; Buhûtî, Keşşâfü'l-kına', $1 / 146$.

48 Fakihler, şehitleri hem dünya hem ahiret şehidi, sadece dünya şehidi ve sadece ahiret şehidi olmak üzere üç kısma ayırmaktadır. Buna göre niyeti Allah rızası olup cephede öldürülen hem dünya hem ahiret şehididir. Cephede öldürülmekle beraber niyeti gösteriş ve ganimet gibi dünyalık olanlar sadece dünya şehididir. Herhangi bir savaşa katılmayıp da salgın hastalıktan ölen, boğulan, yanan, vb. ise sadece ahiret 
M. BAYAR / The Rights of the Dead Over the Alives in Islamic Fiqh | 281

hükmünde olanlar ise yıkanır. Ancak yıkanması durumunda hastalığın başkasına bulaşması tehlikesi varsa ölüye sadece su dökülür bu imkân da yoksa teyemmüm aldırılır. ${ }^{49}$

\subsubsection{Kefenlenmesi}

Ölünün kefenlenmesinin hükmü yıkanmasının hükmü ile benzerlik göstermektedir. Bu sebeple kefenlenmesinin farzı kifaye olduğu konusunda da görüş birliği vardır. ${ }^{50}$ Yıkamakla verilen değer, kefenlemeyle adeta tamamlanmaktadır. ${ }^{51}$

Kefen, bedeni örtebilecek durumdaysa vacip olan tek parçadır. Kefende müstehap olan ise erkeğin üç kadının beş parça olmasıdır. ${ }^{52}$ Kefen, hayatta giyilmesi caiz olan bir örtüden oluşmalıdır..$^{53}$ Şehidin kefeni ise savaştığ 1 elbisesidir. ${ }^{54}$

şehididirler. Ahiret şehitlerinin cenazelerine özel bir muamele yapılmaz. Dünya şehitlerine de şehid uygulaması yapılır ancak ahirette ecri yoktur. bk. Kâsânî, Bedâi 'u's-sanâi', 1/320-325; Nevevî, Ravdatü't-tâlibîn, 2/118-220.

49 Nitekim halen aktif bir hastalık olan koronavirüs hastasının yıkanmasının keyfiyeti ile ilgili bu yönde fetvalar verilmiştir. Din İşleri Yüksek Kurulu 22.03.2020 de konu ile ilgili yayınladığı fetvanın ölünün yıkanması ile ilgili bölümünde tüm şartların zorlanması gerektiğine hükmetmiştir. Diyanet İşleri Başkanlığı, “Din İşleri Yüksek Kurulu Başkanlığı" (Erişim:19.03.2021) Bu fetvalarda sağlı uzmanlarının tavsiyelerinin yerine getirilmesi önerilmektedir. Nitekim hastalığa salgın hükmünü verenler sağlık uzmanlarıdır.

50 Kâsânî, Bedâi 'u's-sanâi', 1/306; Ebû Abdillâh Muhammed b. Alî el-Mâzerî, Şerhu'tTelkîn, thk. Muhammed el-Muhtâr es-Selâmî (Misır: Darü'l-Garbi'l-İslâmî, 2008), 1/1133; Nevevî, Ravdatü't-tâlibîn, 2/109; Buhûtî, Keşşâfü'l-kına', 2/104.

51 Kâsânî, Bedâi 'u's-sanâi', 1/306.

52 Kâsânî, Bedâi 'u's-sanâi', 1/306; Mâzerî, Şerhu't-Telkîn, 1/133; Nevevî, Ravdatü't-tâlibîn, 2/109; Buhûtî, Keşşâfü'l-kına', 2/105.

53 Kâsânî, Bedâi 'u's-sanâi` 1/307; Şirbînî, Mŭğni'l-muhtâc, 2/336.

54 Buhârî, el-Muhîțï'l-Burhân̂̂, 2/170; Ahmed b. Gunaym b. Sâlim en-Nefrâvî, elFevâkihu'd-Devvânî Alâ Risâleti İbn Eb̂̂ Zeydi'l-Kayravânî (Beyrut: Dârü'l-Fikr, 1995), 1/289; Ebû Abdillâh Şemsüddîn Muhammed b. Ahmed b. Ahmed b. Hamza er-Remlî, Nihâyetü'l-muhtâc İlâ şerhi'l-Minhâc (Beyrut: Dârü'l-Fikr, 1404/1984), 2/45; İbn Kudâme, el-Mŭgnî, 2/396. 


\subsubsection{Cenaze Namazının Kılınması}

Diğer uygulamalarda olduğu gibi cenaze namazı da farz-1 kifayedir. ${ }^{55}$ Cumhura göre namazın cemaatle kılınması şart değilken ${ }^{56}$ Mâlikîlerde bir görüşe göre şarttır. ${ }^{57}$

Cenaze namazı kılınış şekli ile diğer namazlardan ayrılmaktadır. Bu sebeple şart ve rükünleri diğer namazlardan farklıdır. Ancak hadesten taharet, necasetten taharet setr-i avret, istikbali kıble ve niyet gibi şartlar cenaze namazı için de geçerlidir. Cenaze namazında sadece vakit şartı yoktur. ${ }^{58}$

Yıkanması caiz olan her ölünün üzerine cenaze namazı da kılınır. Çünkü yıkama, ölüyü üzerinde namaz kılınabilecek duruma getirmektir. ${ }^{59}$ Sadece şehidin yıkanmayacağ 1 ittifakla kabul edilirken üzerinde namaz kılınıp kılınmayacağ 1 ihtilaflıdır. Hanefîler'e göre şehid olanın üzerine namaz k1lınır ${ }^{60}$ diğer mezheplere göre ise namazları k1linmaz. ${ }^{61}$

Hanefîler' de ve Mâlikîler'de cenaze hazır olmalıdır. Gıyâbî cenaze namazı yoktur. ${ }^{62}$ Şâfiî ve Hanbelîler'e göre ise giyâben cenaze namazı k1lınabilmektedir. ${ }^{63} \mathrm{Bu}$ son görüş, ölünün ruhuna yönelik hakların da mevcut olduğunu göstermesi açısından önemlidir.

Hazır olan cenazenin durabileceği yer konusunda farklı görüşler bulunmaktadır. Cenazenin cemaatin ön tarafında ve cemaatin bulunduğu hizada ve taşınır halde değil de yerde bulunması gerektiği konusunda ittifak olmakla beraber bunun başı hizasında mı yoksa gövdesi hizasında

55 Kâsânî, Bedâi 'u's-sanâi', 1/313.

56 Serahsî, el-Mebsît, 2/126; Ahmed b. Muhammed b. Alî b. Hacer el-Heytemî, Tuhfetü'lmuhtâc fî şerhi'l-Minhâc, thk. Mustafâ Muhammed (Beyrut: Dârü İhyâi't-Türasi'l-Arabî, 1357/1983), 3/147; Buhûtî, Keşşâfü'l-kına', 2/111.

57 Haraşî, Şerhu Muhtasari Halîl, 2/17.

58 Zuhaylî, el-Fıkhü'l-İslâmî, 2/499.

59 Kâsânî, Bedâi 'u's-sanâi', 1/306.

60 Kâsânî, Bedâi 'u's-sanâi', 1/325.

61 Mâzerî, Şerhu't-Telkîn, 1/1185-1186, Heytemî, Tuhfetü'l-muhtâc, 3/164; İbn Kudâme, elMŭ̆nî, 2/390.

62 Kâsânî, Bedâi 'u's-sanâi’, 1/312; Haraşî, Şerhu Muhtasar-i Halîl, 2/141.

63 Ebü'l-Hasen Alî b. Muhammed b. Habîb el-Basrî el-Mâverdî, el-Hâvi'l-kebîr, thk. Alî Muhammed Muavvız vd. (Beyrut: Dârü'l-Kütübi'l-İlmiyye, 1419/1999), 3/51; İbn Kudâme, el-Mŭgnî, 2/396. 
mı olacağı konusu tartışmalıdır. Çoğunluğun kanaati erkek olduğu takdirde başın hizasında bulunması gerektiği yönündedir. ${ }^{64}$

Cenaze namazında rükû, secde ve oturuşlar olmadığı için bunlarda okunan zikirler de yoktur. Bu bağlamda ayakta durmak ve ayakta iken dört tekbir getirmek ittifakla rükün olarak kabul edilmiş ancak bu tekbirlerin mahalli konusunda görüş ayrılığı meydana gelmiştir. Hanefîler'in dişındaki Cumhura göre selam da bir rükündür. Rükünlerden niyet ve duada Mâlikî ve Şâfiîler, Fatiha'yı okuma ve Hz. Peygamber'e (s.a.v) salavat getirmede ise Hanbelîler'le Şâfiîler görüş birliği içindedir. Bütün bunlara ek olarak Hanbelîler'de tertip bir rükün olarak zikredilmektedir. Niyet ise Hanefî ve Hanbelîler'de rükün değil şarttır. ${ }^{65}$

\subsubsection{Teşyîi}

Teşyi geniş anlamıyla ölünün ilk ölüm anında cenazesinde bulunmasından defnedildikten sonraya kadar uzanan bir süreçtir. Ancak dar anlamıyla ölünün bulunduğu yerden namaz kılınan yere veya bu yerden de defnedilmeye götürülmesi sürecidir. Omuzlarda taşınması, taşımayanların da beraberinde yürümesi veya cenazeyi takip etmesi süreçlerini içermektedir.

Ölünün teçhiz işlemleri bittikten sonra teşyiine sıra gelir. Ölünün defnedilecek yere götürülmek üzere taşımasının farzı kifaye olduğu konusunda görüş birliği vardır. Yolun çok uzun olması gibi bir özür yoksa omuzlarda taşınması binek üzerinde taşınmasından daha faziletlidir. ${ }^{66}$ Çünkü bu huşuyu daha artırır ve ölüye de daha çok değer verilmiş olur. Ayrıca normal bir hızda olmak en doğrusudur. ${ }^{67}$

\subsubsection{Defnedilmesi}

Ölünün defnedilmesinin farz-1 kifaye olduğu konusunda da icmâ' vardır. ${ }^{68}$ Gömülen yerin kokuyu giderecek ve kefenin bir şekilde çıkarılmasını engelleyecek derinlikte olması yeterlidir. İdeal olan derinlik miktarında ise fukahânın farklı görüşleri vardır. ${ }^{69}$

\footnotetext{
64 Zuhaylî, el-Fıkhü'l-İslâmî, 2/500.

65 Zuhaylî, el-Fıkhü'l-İslâmî, 2/486-491.

66 Kâsânî, Bedâi 'u's-sanâi', 1/309.

67 Haraşî, Şerhu Muhtasar-i Halîl, 2/128.

68 Zuhaylî, el-Fıkhü'l-İslâmî, 2/519.

69 Zuhaylî, el-Fıkhü'l-İslâmî, 2/521-522.
} 
Ölü kefen olan bir örtü ile defnedilir. Ölü denizde olup karaya çıkarılması tehlikeli ise veya karaya taşınana kadar kokma ihtimali varsa denize atılmak zorundadır. ${ }^{70}$ Ölünün öldüğü yerde ve beldede gömülmesi Şâfi'î ve Hanbelîler'de vacip iken ${ }^{71}$ Hanefî ve Mâlikî mezheplerinde öldüğü yerin dişında da gömülmesine cevaz vardır. ${ }^{72}$

\subsubsection{Bedeni Üzerinde Operasyon Yapılmaması}

Özel bir durum olmadığı zaman defnedilmeyle beraber ölünün bedenine yönelik haklar sona erer. Bu bağlamda mezkûr muameleler dışında ölünün bedeni üzerinde tasarrufta bulunmak ve ona zarar vermek caiz değildir. Nitekim Hz. Peygamber (s.a.v) “Ölünün kemiklerinin kırılması diri iken kırılması gibidir"73 buyurmuştur. Bu yasağın zaruretten kaynaklanan bazı istisnaları bulunmaktadır. Klasik dönemde ölünün bedeni üzerinde tasarrufta bulunma ölen annenin karnında yaşayan ceninin kurtarılıp kurtarılamayacağı meselesinde tartışma konusu olmuştur. Ölen kadının karnında bulunan çocuğun canlı olarak kurtarılması ve yaşamaya devam etme ümidi olması durumunda karnının açılabileceği hükmü Hanbelîler'in ${ }^{74}$ dışındaki çoğunluk tarafından caiz görülmüştür. Zira sağ doğabilecek bir çocuğun yaşatılması maslahatı, ölü birinin bedeninin açılmaması maslahatından daha büyüktür. ${ }^{75}$ Ölen kadının karnındaki çocuğun yaşam emareleri devam ettiği sürece gömülmemesi gerektiği konusunda ise görüş birliği bulunmaktadır.

Günümüzde ise ölünün bedenine yönelik müdahale daha ziyade tıbbi ve adli gerekçelerle otopsi yapma veya organ nakli gibi amaçlarla yapılmaktadır. Otopsi, insan vücudunu daha yakından tanıma, ölüm ve hastalık sebeplerinin belirlenmesinde hastalığın vücutta bıraktığı etkiyi görme ve inceleme, cinayet gibi kriminal olaylarda suçun işleniş biçimini

70 Muhammed b. Ahmed el-Cezîrî, el-Fıkh ale'l-Mezâhibi'l-Erba a (Beyrut: Darü'1-Kütübi'1İlmiyye, 1424/2003) 1/485.

71 Nevevî, Ravdatü't-tâlibîn, 2/143; İbn Kudâme, el-Muğnî, 2/380.

72 Buhârî, el-Muhîtü̈'l-Burhânî, 5/359; Mâzerî, Şerhu't-Telkîn, 1/1201.

73 Ebû Dâvud, Süleymân b. Eş’as el-Ezdî es Sicistânî, Sünen, thk. Muhammed Muhyiddîn Abdülhamîd (Beyrut: Mektebetü'l-Asriyye, ts.), "Cenâiz", 20 (No: 3207).

74 Buhûtî, Keşşâfüll-kına', 2/146.

75 Nevevî, el-Mecmî̀', 5/301. 
M. BAYAR / The Rights of the Dead Over the Alives in Islamic Fiqh I 285 teşhir etme işlemidir. ${ }^{76}$ Otopsi; tıbbî ve adlî otopsi olmak üzere iki çeşittir. Tıbbî otopsi; hastalıklar hakkında yeni ve geniş bilgiler sunmak ve insan anatomisini tespit etmek niyetiyle tıp öğrencilerine yaptırılmaktadır. Adli otopsi ise ölümü doğal yoldan gelişmeyen bir kişinin ölüm sebebinin araştırılması için beden üzerinde gerekli müdahalenin yapılmasıdır. ${ }^{77}$ Doktrinde otopsi ile daha ziyade bu tür otopsi kastedilmektedir. Diğer otopsi işlemi için ise kadavra kavramı kullanılmaktadır. Çünkü bu tür otopside yasal süresi bittikten sonra sahipsiz kalan cesetler kadavra olarak verilmektedir.

Müdahalenin boyutu açısından ise bedenin dışının otopsisi ve içinin otopsisi olmak üzere iki tür otopsiden bahsedilmektedir. Diş bedenin otopsisinde genelin görüşü caiz olduğu yönündedir. Çünkü bu durum, yaralı olan bir kişinin yara durumunu incelemekten ibarettir. İçi otopsinin hükmü konusunda ise farklı görüşler bulunmaktadır. Çağdaş İslam hukukçularının çoğunun görüşü otopsinin caiz olduğu yönündedir. Çünkü tıp eğitiminin verilmesi ve doğal olmayan ölümlerin muhtemel faillerinin tespit edilmesi işlemlerinde bedene zarar vermeme maslahatından daha büyük maslahatlar bulunmaktadır. ${ }^{78}$

Organ nakli de iç otopsiden farklı değildir. Ancak oluşum sebebiyle otopsiden ayrılmaktadır. Otopsiden geçmediği sürece organ nakli de gerçekleşmemektedir. Otopsi engeline takılan organ nakilleri olabilmektedir. ${ }^{79}$ Organ nakli de diriden diriye organ nakli ve ölüden diriye organ nakli olmak üzere iki kısma ayrılır. Konumuz ile ilgili olan ölüden diriye yönelik organ nakline gelince; bu konuda farklı görüşler bulunmaktadır. İnsan bedeninin ölü de olsa dokunulmaz olduğu ilkesinden yola çıkanlar organ naklinin caiz olmadığını belirtirken, bir diriyi yaşatmanın bir ölünün bedenine zarar vermeme maslahatından daha büyük olduğunu söyleyenler ise caiz olduğu yönünde karar

76 Türk Hukuk Kurumu, Türk Hukuk Lugatı (Ankara: Başbakanlık Basımevi, 1991) 272; M. Fatih Turan, "Fıkhî Açıdan Otopsi”, İslam Hukuku Araştırmaları Dergisi 23 (2014), 273.

77 Turan, "Fıkhî Açıdan Otopsi", 274.

78 Geniş bilgi için bk. Turan, "Fıkhî Açıdan Otopsi”, 290-293.

79 Örneğin bk. Cumhurbaşkanlığı İletişim Başkanlığı, “Anadolu Ajansı” (Son Erişim: 19.03.2021). 
vermişlerdir. Başta Diyanet İşleri Başkanlığı olmak üzere diğer fetva kurullarının mütalaası bu yöndedir..$^{80}$

\section{2. Ölünün Terikesine İlişkin Haklar}

Ölünün ardından bıraktıklarına terike denilmektedir. ${ }^{81}$ Hanefî mezhebinde terike ile kastedilen mali haklar iken cumhura göre terike ölünün bıraktığı hakların tamamına denir. ${ }^{82}$ Pozitif Türk hukukunda da terike malvarlığı olarak ele alınmakta ancak küçük bir değişiklikle tereke olarak ifade edilmektedir. Oysa Türk Hukuk Lügatinde tereke şeklindeki telaffuzun galat olduğu belirtilmiştir..$^{83}$

Ölümle birlikte ölünün hakları zimmetinden terikesine geçer. ${ }^{84}$ Ölünün sırf mali hakları ve sırf şahsi haklarının yanında bazen de iki hakkın beraber bulunduğunu belirtmek gerekir. Yukarıda ölünün zimmetindeki hakların bir kısmının belirli bir süre devam ettiği açıklanmıştı. Şahsa bağlı hakların ölümle sona ereceği ve mirasçılara intikal etmeyeceği, buna karşılık ölümün sırf mala bağlı hakları düşürmeyeceği genellikle kabul edilir. ${ }^{85}$ Alacak ve irtifak hakkı gibi malvarlığı hakları varisler intikal eder. Hanefîler hanım nafakasını bu genel kuraldan istisna etmişlerdir. Onlara göre, ister karşılıklı rıza ile isterse mahkeme kararıyla belirlenmiş olsun, nafakasını alamadan ölen hanımın nafaka alacağ 1 düşer. ${ }^{86}$ Hidane ve beden bütünlüğü gibi şahıs hakları ise ölümle ile biter ve varislerine intikal etmez. Şahsî ve malî hakların karma olduğu haklarda ise fakihlerin bakış açılarına bağlı olarak değişik görüşler mevcuttur. ${ }^{87}$

Terikeye geçen hakların yaşayanlar tarafından hangi aşamada ifa edileceği konusu da fıkıh eserlerinde ele alınmaktadır. Ölünün teçhizinin

80 Fetva kurullarının kararları için bk. Ahmet Yaman, "İslam Hukuku Açısından Organ Nakli ve Beyin Ölümü", Tıp, Etik, Din, Sosyoloji ve Hukuk Bağlamında Organ Nakli Sorunlar ve Çözüm Önerileri Sempozyumu (Malatya: y.y., 2014), 30-32.

81 Zeynüddîn Muhammed b. Ebî Bekr er-Râzî, Muhtâru's-sihâh, thk. Yûsuf eş-Şeyh Muhammed (Beyrut: Mektebetü'l-Asriyye, 1420/1999), "terike", 46.

82 Zuhaylî, el-Fıkhü'l-íslâmî, 8/269-270.

83 Türk Hukuk Kurumu, Türk Hukuk Lugatt, 336.

84 Mâverdî, el-Hâvi'l-kebîr, 6/273.

85 Esen, "Ölüm”, 34/39.

86 Serahsî, el-Mebsût, 5/19/6; Hüseyin Esen, "İslâm Hukukunda Ölümün Mali Hak ve Borçlara Etkisi", Cumhuriyet Üniversitesi İlahiyat Fakültesi Dergisi 9/1 (Haziran 2005), 60.

87 Geniş bilgi için bk. Tala, Ölümün Özel Haklara Etkisi, 58 vd. 
ve borçlarının ödenmesinin vasiyetini yerine getirilmesinden ve miras olarak varislerine dağıtılmasından önce olacağı konusunda ittifak olmakla beraber teçhiz ve borçların ödenmesi işlemlerinden hangisinin önce yerine getirileceği konusunda ihtilaf vardır. Ölünün borçları varsa Hanefî, Mâlikî ve Şâfiîler'e göre önce borçları ödenir sonra teçhizine başlanır. ${ }^{88}$ Hanbelîler'e göre ise teçhiz borçların ödenmesinden önce olur. ${ }^{89}$

\subsubsection{Borçlarının Ödenmesi}

Ölünün borçları ödenmeden terikesinin varislere taksim edilmeyeceği konusunda görüş birliği vardır. Ancak bunun hangi tür borçlar olduğu konusu ihtilaflıdır. Borçları ayni borçlar ve zimmetteki borçlar diye ikiye taksim ettiğimizde burada kastedilen ayni borçlar olmaktadır. Zimmetindeki borçlar ise yukarıda belirtildiği gibi düşmekte veya terikeye intikal etmektedir.

Borçları kul hakkı ve Allah hakkı olarak değerlendirdiğimizde ise ölünün teçhizi Allah hakkı, bahsedilen borçlar ise kul hakkı olmaktadır. $\mathrm{Bu}$ konudaki fakihlerin ihtilafı da söz konusu bakış açısına dayanmaktadır. Şâfiîler hac ve kefaretleri de Allah hakkı bağlamında örnek verip bir görüşlerinde bunların kul haklarından önce verilmesi gerektiğini belirtmektedir.90 Hanefîler ölümle Allah haklarının sakıt olduğunu belirtirken ${ }^{91}$ Mâlikîler kul haklarının Allah haklarından öncelikli olduğunu düşünmektedir. ${ }^{92}$ Hanbelîler ve diğer görüşlerinde Şâfiîler ikisinin müsavi olduğu görüşünü öne sürmüşlerdir. ${ }^{93}$ Hanefiler'e göre ayrıca ölünün hayatta sağlıklı iken belirtiği borçlar veya ölüm hastası iken belirtip de delillerle onaylanan borçları kendisinin ölüm hastalığ1

88 Muhammed Emîn Alâuddîn b. Ömer. b. Âbidîn, Reddü'l-muhtâr ale'd-Dürri'l-muhtâr (Beyrut: Dârü'l-Fikr, 1412/1992), 6/759; Nefrâvî, el-Fevâkihu'd-Devvânî, 2/33; Nevevî, Ravdatü't-tâlibîn, 6/3.

89 Buhûtî, Keşşâfü'l-kına', 2/106.

90 Ebü'l-Meâlî Rüknüddîn Abdülmelik b. Abdillâh b. Yûsuf el-Cüveynî, Nihâyetü'lmațlab fì dirâyeti'l-mezhheb, thk. Abdülazîm Mahmûd ed-Dîb (Cidde: Dârü'l-Minhâc, 1428/2007), 3/396.

91 Kâsânî, Bedâi 'u's-sanâi’, 2/53.

92 Haraşî, Şerhu Muhtasari Halîl, 8/197.

93 Cüveynî, Nihâyetü'l-mațlab, 3/396; Buhûtî, Keş̧âfü'l-kına', 2/182. 
anında belirttiği borçlarından önce verilir. ${ }^{94}$ Cumhura göre ise hepsi müsavidir. ${ }^{95}$

Kul haklarında borçların ödenmesi ile ölü zimmetteki haklardan beri olur. Allah haklarındaki borçların ne olacağı ile ilgili mesele ölünün ruhuna yönelik haklar başlığında zikredilecektir.

\subsubsection{Vasiyetinin Yerine Getirilmesi}

Bahsedilen prosedüre göre borçlar ödendikten sonra ölünün hayatta iken vasiyet ettiklerinin yerine getirilmesine sira gelir. Vasiyet edilen malın murisin malının üçte birini geçmemesi gerekir. Ancak varislerin rızası varsa daha fazlası da vasiyet edilebilir. Vasiyetlerin yerine getirilmesinin borç ve teçhizden sonra mirasın varislere dağıtılmasından önce olduğu konusunda ittifak vardır. ${ }^{96}$

\subsubsection{Mirasının Taksim Edilmesi}

Son olarak ölünün malları varisleri arasında bölünür. Böylece ölünün hiçbir borcunun kalmadığı varsayılır. Teçhiz hakkının dışındaki haklar aslında ölü için bir borç sayıldığından yaşayanların da haklarıdır. $\mathrm{Bu}$ bakımdan mirasın dağıtılması varislerin de hakkının ödenmesi anlamına gelmektedir. Mirasın dağıtılması ve kimlere verileceği ile ilgili büyük bir ilim doğmuş olup bu ilme feraiz denilmektedir. Kuralları hayli fazla olduğundan burada zikredilmeyecektir. Çalışmamızın muhtevası açısından ölünün terikesine ilişkin son hak olduğunun bilinmesi kâfidir.

\section{3. Ölünün Ruhuna Yönelik Haklar}

Ölüm tariflerinde de görüldüğü üzere ölümle birlikte ruh cesetten ayrılmakta, ruhun kabzedilmesi ile beden üzerindeki tasarrufu sona ermektedir. Ruhun bedendeki tasarrufu kesilince amel sahası da ortadan kalkmaktadır. Diğer yandan ölünün herhangi bir etkisinin olmadığı ve ölümünden sonra yaşayanların kendisi için yerine getirdikleri ameller de mevcuttur. Bu amellerin diriler tarafından ifası ölünün ruhu için bir hak olarak değerlendirilebilir. Bu bölümde ruha yönelik haklar ile ruha etki edildiğine inanılan meselelerin fıkhi hükümlerinden bahsedilecektir.

\subsubsection{Kelime-i Tevhidin veya Kelime-i Şehadetin Telkini}

Telkin, ölüm döşeğindeki kişiye kelime-i tevhidin veya kelime-i şehadetin hatırlatılması ve cenazenin defnedilmesinin ardından bir

94 Serahsî, el-Mebsût, 18/26-27.

95 Karâfî, ez-Zahîre, 9/261; Mâverdî, el-Hâvi'l-kebîr, 7/2; İbn Kudâme, el-Muğnnî, 5/158.

96 Zuhaylî, el-Fıkhü'l-İslâmî, 8/276. 
M. BAYAR / The Rights of the Dead Over the Alives in Islamic Fiqh I 289

kişinin kabrin başında yüksek sesle ölüye iman esaslarını okuması işlemleridir. ${ }^{97}$ Buna göre biri ölmek üzere iken diğeri defnedildikten sonra okunan iki tür telkin bulunmaktadır. Ölmek üzere olana kelime-i tevhidi veya kelime-i şehadeti telkin edip söylemesine yardımcı olmak ittifakla sünnettir. ${ }^{98}$ Nitekim Hz. Peygamber (s.a.v) "Ölülerinize La İlahe İllellah'ı telkin edin" 199 buyurmuştur.

Bununla birlikte telkin denildiğinde öldükten sonra mezar başında ölüye bazı sözlerin hatırlatılması akla gelmektedir. Bu kısımdaki telkin, ruhun tekrar bedene dönmüş olduğu ve sorgu meleklerinin ölüyü sorguya çekmeye başlayacakları inancına bağlı olarak ölüye yardımcı olma maksadıyla okunmaktadır.

Ölünün defnedildikten sonra mezarının başında okunan telkinin hükmü konusunda İslam hukukçularının farklı görüşleri vardır. Genel eğilim mükellef için telkin okumanın caiz olduğu yönündedir. Bu telkinin vacip olmadığ 1 konusunda ittifak olmakla beraber müstehap, mübah veya mekruh mu olduğu tartışmalıdır. Hanefîler'e ve Mâlikîler'e göre ne nehyedilir ne de emredilir ${ }^{100}$ Şâfiî ve Hanbelîler ise telkini müstehap olarak görmektedir. ${ }^{101}$. Meselenin uhrevi boyutunun olması sebebiyle âlimler öteden beri bu uygulamaya şahit oldukları halde müdahalede bulunmamış ve adeta bu konuda sükûtî icmâ' meydana gelmiştir.

\subsubsection{Kendisine Dua ve İstiğfarda Bulunulması}

Ölünün amellerinin kesildiği ancak müminlerin ona dua etmeleri veya kendisinin bir sadak-ı cariye bırakması gibi yaşarken sebep olduğu amellerin değerlendirilmesinin devam ettiği yukarıda söylenmişti. Kendisinin yaşarken sebep olmadığ farklı görüşler ileri sürülmüştür. Ölünün sebep olmadığı amellerin başında kendisine dua ve istiğfarda bulunulması gelmektedir. Çoğunluk

97 Haci Mehmet Günay, “Telkin”, Türkiye Diyanet Vakfi İslâm Ansiklopedisi (İstanbul: TDV Yayınları, 2011), 40/404.

98 Kâsânî, Bedâi 'u's-sanâi', 1/299; Haraşî, Şerhu Muhtasari Halîl, 2/122; Şirbînî, Muğgi'lmuhtâc, 2/5; İbn Kudâme, el-Mŭ̆nî, 2/335.

99 Müslim, “Cenâiz", 11.

100 Molla Hüsrev Muhammed b. Ferâmurz b. Alî. Dürerü'l-hükkâm fi şerḥi Gureri'l-aḥkâm. (Misır: Dârü İhyâi Kütübi'l-Arabî, ts.), 1/160; Nefrâvî, el-Fevâkihu'd-Devvân̂̂, 1/284.

101 Şirbînî, Muğni'l-muhtâc, 2/60; Zeynüddîn Merî̂ b. Yûsuf b. Ebî Bekr el-Kermî, Delîlü'ttâlib li-neyli'l-mețâlib, thk. Ebû Kuteybe Muhammed el-Feryâbî (Riyad: Dâru't-Tayyibe, 1425/2004), 71; Zuhaylî, el-Fıkhü'l-İslâmî, 2/536. 
bunun caiz olduğu kanaatindedir. Bu konudaki en büyük delil “Onlardan sonra gelenler: Rabbimiz bizi ve bizden önce imanla geçenleri bağışla"102 âyetidir.

Mütevâtir sünnetle sabit olan cenaze namazından maksadın da ölüye dua olduğu belirtilmektedir. ${ }^{103} \mathrm{~Hz}$. Peygamber'in (s.a.v.) ölen oğlu Hz. İbrahim'in namazını çocuk masum olduğu için kılmadı ̆̆ı şeklindeki rivayetler bize namazın istiğfar işlevini gördüğünün diğer bir delilidir. ${ }^{104}$ Hz. Peygamber'in (s.a.v.) defnedilen biri için de, "Kardeşiniz için istiğfar ediniz ve ona tesbit (sorular karsısında şaşırmadan cevap verme hali) isteyiniz. Çünkü o şu anda sorguya çekilmektedir" ${ }^{\prime \prime 05}$ buyurduğu nakledilmektedir. Yanı sıra ölenlere Hz. Peygamber'in (s.a.v), dua ettiğine dair birçok yoldan sahih hadisler gelmiştir.

İman ehli olmayana istiğfarın ise herhangi bir karşıllı̆ı yoktur. ${ }^{106}$ İmansızlık onların bağışlanması önünde bir engeldir. ${ }^{107}$ İmansız ölen bir kişinin iman etmesi geçersiz olduğu gibi başkalarının onlar için amel etmeleri de geçersizdir.

\subsubsection{Kuran Okumaktan Elde Edilen Sevabın Hediye Edilmesi}

Ölüye Kur'ân okuma konusunda kısmen ihtilaf mevcuttur. İhtilafın sebebi, dua ve istiğfar yerine yaşayan kişi tarafından okumadan elde edilen sevabın ölünün ruhuna hediye edilmesi işlemidir. Ölünün üzerine okuma ile ilgili olarak Hanefîler' in ve Hanbelîler'in görüşü caiz olduğu yönündedir. ${ }^{108}$ Ancak bunun ücret karşılığında yapılmaması önem arz etmektedir. ${ }^{109}$ İlk dönem Mâlikîler ve Şâfiîler ölünün ruhuna okumadan

102 el-Haşr 59/10.

103 Kâsânî, Bedâi'u`s-sanâi', 1/313-314; Haraşî, Şerhu Muhtasar-i Halîl,1/211; Mâverdî, elHâvi'l-kebîr, 2/501.

104 Nevevî, el-Mecmủ, 5/216.

105 Ebû Davud, "Cenâiz", 72.

106 et-Tevbe $9 / 80$.

107 et-Tevbe $9 / 84$.

108 İbn Âbidîn, Reddü'l-muhtâr, 2/243; Ebü'l-Hasen Alâüddîn Alî b. Süleymân b. Ahmed el-Merdâvî, el-İnsâffî̀ ma 'rifeti'r-râcihi mine'l-hilâf (Beyrût: Dâru İhyâi't-Turâsi'l- 'Arabî, ts.), $2 / 559$.

109 Diyanet İşleri Başkanlığı Din İşleri Yüksek Kurulu fetvalarında, "Pazarlık yapılmadan ve paradan söz edilmeden Allah rizası için Kur'an okumuş veya hatim indirmiş olan bir kimseye, hediye olarak münasip bir miktar teberruda bulunmakta dinen bir sakınca görülmemektedir. Fakat bir kimsenin, geçmişlerinin ruhuna bağışlanmak üzere başka kimselere 
M. BAYAR / The Rights of the Dead Over the Alives in Islamic Fiqh I 291 elde edilen sevabı bağışlamayı "Kişiye ancak çalıştı̆̆ııın karşılı̆̆ vardır"110ayetinin hükmünden yola çıkarak kabul etmemişlerse de daha sonraki Mâlikîler ve Şâfiîler caiz görmeye başlamışlardır. ${ }^{111}$

Şâfiî mezhebinde bir görüş daha vardır. Bu görüşe göre, Kur'ân okuma sevabının ulaşması için, ölünün arkasından dua edilmesi lazımdır. Dua edilmezse, sevap ölüye ulaşmaz. Bundan dolayı Şâfiîler, Kur'an okuduktan sonra şöyle derler: "Allah'ım! Okumuş olduğum Kur'an'ın sevabının bir mislini, falanca kişiye ulaştır."112

Ölü yakınlarının taziyeleri üç gün kabul ettikten sonra ölü için ayrı bir toplantı yapılarak mevlit okunması ise caiz görülmemektedir. Çünkü yedinci, kırkıncı ve elli ikinci gün merasimi veya duası gibi zaman ve şekle bağlanmış bir görev yoktur. Bunların hiçbir dinî dayanağı da bulunmamaktadır. ${ }^{113}$

\subsubsection{Eda Edemediği İbadetlerine İlişkin Hakların İfası}

Terikeye yönelik haklar başlığı altında ölünün kul haklarına ilişkin hükümlerine değinilmişti. Allah hakları ile ilgili hükümleri terike kapsamına dâhil olmadığından ölünün ruhuna yönelik haklar başlığında zikretmeyi uygun bulduk.

Normal şartlarda Allah hakkı sakıt olmaz. Ancak kişi yaşadığ sürece bunu yapamayacak durumda ise oruçta olduğu gibi fidye ile bu borcu düşürebilmektedir. Öldükten sonra bunun imkânına gelince; bu konuda ibadete göre değişen hükümler ve fakihlerin detaylarda farklı görüşleri bulunmaktadır. Bir kişi öldüğünde üzerinde kaza namazı veya kaza orucu varken yahut veremediği zekâtı ve ifa edemediği haccı varsa neler yapilabilir?

Fakihlerin büyük çoğunluğuna göre namaz kılmayan ve kazasını kılmadan ölen kişinin yerine kaza namazı kılınmaz. Ölümle birlikte bu hak sakıt olur. ${ }^{114}$ Hanefî ve Şâfiîler'in bir görüşlerine göre ölünün

\footnotetext{
Kur'an-ı Kerim okutması, hatim indirtmesi yerine, bildiği kısa sureleri tekrar etmek suretiyle de olsa, bizzat kendisinin okuması daha faziletli ve daha sevaptır", demektedir. Bk. Din İşleri Yüksek Kurulu, Fetvalar (Ankara: Diyanet İşleri Başkanlığı Yayınları, 2018), 416.

110 en-Necm 53/59.

111 Haraşî, Şerhu Muhtasar-i Halîl, 2/137; Heytemî, Tuhfetü'l-muhtâc, 7/74.

112 Heytemî, Tuhfetü'l-muhtâc, 6/159.

113 Din İşleri Yüksek Kurulu, Fetvalar, 222.

114 Zeynüddîn b. İbrâhîm b. Muhammed el-Mısrî b. Nüceym, el-Bahrü'r-râik şerhu Kenzi'ddekâik (Kahire: Dârü'1-Kitâbi'1-İslâmî, ts.), 2/307; Ebû Abdillâh Şemsüddîn Muhammed
} 
kılmadığı namazlarının yerine belirli miktarda yoksullara yedirme şeklinde fidyesinin verilmesi caizdir. ${ }^{115}$

Orucun tutulmama sebebine gelince; oruç tutmama ya ölene kadar süren bir mazeret durumundan kaynaklanır veya mazeret olmadan erteleme sebebiyle olur. İkisi farklı hükümlere tabidir. Ölene kadar şer î bir engel sebebiyle oruç tutamayan bir kişinin hiçbir şekilde sorumlu olmadığı konusunda fakihlerin görüş birliği vardır. Bu sebeple bunun yerine oruç tutulması veya fidye yedirilmesine gerek yoktur. Şer `̂̀ bir mazeret olmadan erteleyen kişinin de yerine oruç tutulmayacağ konusunda çoğunluk hem fikirdir. ${ }^{116}$

Zekât konusunda ise âlimlerin farklı görüşleri vardır. Şâfiî ve Hanbelîler'e göre ölüm zekât hakkını ortadan kaldırmaz. Bu sebeple ölünün veremediği zekâtları terikesinden karşılanır. ${ }^{117}$ Hanefîler'e göre ölü vasiyet etmemişse terikesinden karşılanmaz. ${ }^{118}$ Mâlikîler ise malın zekâtını ve ürünlerin zekâtını farklı değerlendirmişlerdir. Onlara göre mali olmayan zekâtlar terikeden karşılanır ancak mali olanlar ölünün vasiyet durumuna göre değişir. ${ }^{119}$

Haccın ifasının kendisi vasiyet etmesi durumunda bunun yerine getirileceği konusunda ittifak vardır. Vasiyet etmediği takdirde mezheplerin bu konuda farklı görüşleri vardır. ${ }^{120}$

Görüldüğ̈̈ kadarıyla ölünün ifa etmediği ibadetlerin sorumluluğunun ortadan kaldırılması ya yerine aynı ibadet ifa edilerek veya fidyesi verilerek yapılmaktadır. Fidyesinin verilmesinin özellikle bedeni ibadetlerde ön planda olduğu anlaşılmaktadır.

\subsubsection{Mezarına Zarar Verilmemesi}

Mezara ilişkin hakların ilki mezarın yapısı, diğeri ise yaşayanlar tarafından ziyaret edilmesidir. Ölünün gömülmesi kısmında da

b. Muhammed b. Abdirrahmân el-Hattâb, Mevâhibü'l-celîl li-şerḥi Muhtasarı Halîl (b.y.: Dârü'l-fik, 1412/1992), 2/543; Şirbînî, Muğni'l-muhtâc, 2/173; Buhûtî, Keşşâfü'l-kına, 2/336.

115 İbn Nüceym, el-Bahrü'r-râik, 2/307; Şirbînî, Muğgi'l-muhtâc, 2/173.

116 Kâsânî, Bedâi'u's-sanâi', 2/103; Şirbînî, Muğni'l-muhtâc, 2/172; Buhûtî, Keşşâfü'l-kına, 2/336.

117 Nevevî, Ravdatü't-tâlibîn, 7/106; İ̉n Kudâme, el-Mŭ̆nî, 2/509.

118 Kâsânî, Bedâi'u`s-sanâi', 2/54.

119 Haraşî, Şerhu Muhtasar-i Halîl, 8/184.

120 Kâsânî, Bedâi'u's-sanâi', 2/222; Nevevî, el-Mecmû' 7/98; Buhûtî, Keşşâfü'l-kına, 2/336. 
M. BAYAR / The Rights of the Dead Over the Alives in Islamic Fiqh I 293 belirtildiği üzere kabir belirli bir derinlikte olmalıdır. Böylece mezara zarar verme ihtimalinin önüne geçilmiş olur. Mümkün mertebe iki kişi aynı kabre konulmamalıdır. Ancak ölü sayısı çok, yer sınırlı ve kazıma imkânları da yok ise aynı yere gömülebilirler. ${ }^{121}$

Mezar tahripten, kaba davranışlardan muhafaza edilmelidir. Mezarların üzerinde yürümekten kaçınmalıdır. ${ }^{122} \mathrm{Bu}$ ölünün manevi değerine bir hakaret içermektedir.

Mezarlar ziyaret edilebilir. Hz. Peygamber (s.a.v) şirk tehlikesi sebebiyle önceleri bunu nehyettiğini artık ziyaret edebileceklerini bir hadisinde bildirmektedir. ${ }^{123}$ Ancak ziyaretin ölüye dua veya Kur'ân okuma ile sinırlı tutulması gerekir. Mezarı takdis etmekten sakınılmalıdır. Yaşayanların ölümü hatırlamaları açısından da mezarların ziyareti önemlidir.

\subsubsection{Hakkında Güzel Konuşulması}

Diri hakkında kötü konuşmak bile haram iken kendisini savunmaktan mahrum olan bir ölü hakkında kötü konuşmak daha büyük bir günahtır. Diri olanın giybeti ölü eti yemekse ölü olanın giybetini yapmak bundan daha kötüdür. Kaldı ki ölü yaptıkları hakkında hesabını vermeye başlamıştır. Onu hala dünyada düşünerek ondan hesap sormak çok çirkin bir iştir.

Ancak ölü açıktan günah işliyorsa ve bidat ehli biri ise yaşayanları ondan korumak gibi bir maslahata binaen kötülüklerini anlatmak caiz görülmektedir. Müslümanları uyarmak, yolundan yürümelerini önlemek, halinden ibret almalarını temin etmek niyetiyle bazı ölülerin kötülüklerini anmak caizdir. ${ }^{124} \mathrm{Bu}$ yönüyle diri olanın giybetiyle aynı hükümlere tabi olduğu görülmektedir.

\section{Sonuç}

Ölümün bir yok oluş olmadığının bir alameti olarak ölü, diriler üzerinde birçok sorumlulukları doğurmak suretiyle bu âlemden diğer âleme göçmektedir. Kendisinin genel anlamda amel defteri kapanıorsa da geride kalanlara yönelik bir etki /eser bırakmışsa veya dirilerin ona karşı yerine getirmeleri gereken bazı görevlerin yerine getirilmesi gibi

121 Haraşî, Şerhu Muhtasar-i Halîl, 2/133.

122 Kâsânî, Bedâi'u's-sanâi', 1/320.

123 Müslim, "Cenâiz", 11 (977).

124 Seyyid Sâbık, Fıkhü's-sünne (Beyrut: Darü'l-Kütübi'l-Arabî, 1397/1977), 558. 
sebeplerle açık kalmaya devam etmektedir. Bu sebeple öldükten sonra sadece terikesine yönelik değil, bedenine ve ruhuna da yönelik dirilerin sorumlulukları bulunmaktadır.

Konu ile ilgili hükümlerden anlaşıldığı üzere insanın ölüsü de dirisi gibi değerlidir. Diğer canlılarda olduğu gibi doğrudan değil bir dizi dini vecibe yerine getirildikten sonra mezar denilen özel bir yerde defnedilmektedir. İnsanda öldükten sonra sadece ruh kalmakta ise de bedenin Allah'ın özel bir ikramıyla en güzel şekilde yaratılmış olması ve ruhun yerleşim yeri olması gibi sebeplerle ölümden sonra da değeri ve dokunulmazlığı devam etmektedir.

Ölüm konusu ile ilgili diğer çalışmalara bakıldığında ölüler ile ilgili hükümlerin genel olarak terike çerçevesinde ele alındıkları veya cenaze ahkâmı konusu başlı̆̆ı altında teferruata girildiği görülmektedir. Bu çalışmayla birlikte kısaca da olsa ölülere yönelik hakların kapsamının çıkarılmış olduğu, dar anlamda ölünün haklarının sadece terikesiyle sınırlı olmadığı bedeni üzerinde ve ruhuna yönelik haklarının da olduğu gerçeğinin gösterilmiş olduğu düşünülmektedir.

Ölünün ruhlarına dua ve ölünün bedenine müdahalelerin hükümleri başta olmak üzere kimi uygulamalar günümüz Müslümanları tarafından hala da araştırılmaktadır. Çalışmada bu tür güncel meselelere detaylarına girmeye gerek kalmaksızın değinilmiştir. Böylece ölüye ilişkin hakları çerçevesinde güncel bazı meselelerin çözümüne de katkıda bulunduğu düşünülmektedir.

Ölümün mahiyeti hakkında her geçen gün yeni gelişmelerin meydana geldiği açıktır. Ölümün bir gün herkesin başına gelecek bir olay olması ve bu dünya hayatını tamamlayan kişinin tekrar diriltileceği güne kadar geçen bir süreci içermesi konuyu önemli kılmaktadır. Konu ile ilgili çalışmaların her alanda olduğu gibi fıkıh alanında belli aralıklarla sürdürülmesi önem arz etmektedir. Bu çalışmayla kısmen de olsa konunun güncelliğine yardımcı olunduğu ümit edilmektedir. 


\section{Kaynakça}

Bardakoğlu, Ali. "Hak". Türkiye Diyanet Vakfı İslâm Ansiklopedisi. 15/139151. İstanbul: TDV Yayınları, 1997.

Begavî, Ebû Muhammed Muhyissünne el-Hüseyn b. Mes'ûd b. Muhammed el-Ferrâ'. et-Tehzîb. thk. Adil Ahmed Abdülmevcûd vd.. 8 Cilt. Beyrut: Dârü'l-Kütübi'l-İlmiyye, 1418/1997.

Bereketî, Muhammed Umeym el-İhsan el-Müceddidî. et-Ta'rîfâtü'lfikhiyye. Beyrut: Dârü'l-Kütübi'l-İlmiyye, 1424/2003.

Buhârî, Ebû Abdillâh Muhammed b. İsmail. el-Câmi 'u'ș-ṣahîh. thk. Muhammed Züheyr b. Nasr. 9 Cilt. b.y.: Dârü Tavki'n-Necât, $1422 / 2001$.

Buhârî, Burhânüddîn Mahmûd b. Ahmed b. Abdilazîz. el-Muhîtü'lBurhânî fi'l-fikhi'n-Nu 'mânî. thk. Abdülkerîm Sâmî el-Cündî. 9 Cilt. Beyrut: Dârü'l-Kütübi'l-İlmiyye, 1424/2004.

Buhûtî, Mansûr b. Yûnus. Keşşâfü'l-kına`an metni'l-İkna`. 6 Cilt. Beyrut: Dârü'l-Kütübi'l-İlmiyye, ts.

Cezîri, Muhammed b. Ahmed. el-Fıkh ale'l-mezâhibi'l-erba`a. 5 Cilt. Beyrut: Darü'l-Kutubi'l-İlmiyye, 1424/2003.

Cumhurbaşkanlığı İletişim Başkanlığı. "Anadolu Ajansı". (Son Erişim: 19.03.2021). https://www.aa.com.tr/tr/turkiye/organ-nakli-otopsiengeline-takildi/183067.

Cüveynî, Ebü'l-Meâlî Rüknüddîn Abdülmelik b. Abdillâh b. Yûsuf. Nihâyetü'l-mațlab fi dirâyeti'l-mezheb. thk. Abdülazîm Mahmûd edDîb. 20 Cilt. Cidde: Dârü'l-Minhâc, 1428/2007.

Demîrî, Tâcüddîn Behrâm b. Abdillâh b. Abdilazîz. Tahbîru'l-Muhtasar. thk. Ahmed b. Abdilkerîm Necîb vd.. 5 Cilt. Saraybosna: Merkezu Necibuveyh, 1434/2013.

Diyanet İşleri Başkanlığı. "Din İşleri Yüksek Kurulu Başkanlığı". (Son Erişim 19.03.2021). https://kurul.diyanet.gov.tr/CevapAra/38362/salgin-hastalik-durumunda-cenaze-namazi-ve-definislemlerinin-dini-hukmu-nedir?enc=QisAbR4bAkZg1HImMxXRn2t8ij\%2beDtMkJdRGirgyeb8\%3 $\underline{\mathrm{d}}$

Diyanet İşleri Başkanlığı. Din İşleri Yüksek Kurulu, Fetvalar. Ankara: Diyanet İşleri Başkanlığı Yayınları, 2018. 
296 | M. BAYAR/İslam Fıkhında Ölünün Yaşayanlar Üzerindeki Hakları

Ebû Dâvud, Süleymân b. Eş’as el-Ezdî es-Sicistânî. Sünen. thk. Muhammed Muhyiddîn Abdulhamîd. 4 Cilt. Beyrut: Mektebetü'lAsriyye, ts.

Ebû Yahyâ Muhammed Hasen. Hukûku'l-meyyit ve Ahkâmuh fi'l-İslâm. Umman: Dârü Yafa'l-İlmiyye, 1431/2010.

Esen, Hüseyin. "İslam Hukukunda Ölümün Mâlî Hak ve Borçlara Etkisi". Cumhuriyet Üniversitesi İlahiyat Fakültesi Dergisi 9/1 (Haziran 2005), 55-86.

Esen, Hüseyin. “Ölüm”. Türkiye Diyanet Vakfi İslâm Ansiklopedisi. 34/38-40. İstanbul: TDV Yayınları, 2007.

Feyyûmî, Ahmed b. Muhammed b. Alî. el-Misbahu'l-münîr. Beyrut: Mektebetü Lübnan, 1987.

Gazzâlî, Ebû Hâmid Muhammed b. Muhammed. İhyâu ulûmi'd-dîn. 4 Cilt. Beyrut: Dârü'l-Ma'rife, ts.

Günay, Hacı Mehmet. "Telkin”. Türkiye Diyanet Vakfı İslâm Ansiklopedisi. 40/404-406. İstanbul: Türkiye Diyanet Vakfı, 2011.

Hacak, Hasan. İslam Hukukunun Klasik Kaynaklarında Hak Kavramının Analizi. İstanbul: Marmara Üniversitesi, Sosyal Bilimler Enstitüsü, Doktora Tezi, 2000.

Haraşî, Muhammed b. Abdillâh. Şerhu Muhtasari Halîl. 8 Cilt. Beyrut: Dâru'l-Fikr, ts.

Hattâb, Ebû Abdillâh Şemsüddîn Muhammed b. Muhammed b. Abdirrahmân Mevâhibü'l-celîl li-şerhi Muhtasarı Halîl. b.y.: Dârü'lfik, 1412/1992.

Ilîş, Ebû Abdillâh Muhammed b. Ahmed b. Muhammed. Minehü'l-celîl Şerhü Muhtasari Halil. 9 Cilt. Beyrut: Dâru'l-fikr, 1409/1989.

İbn Ẩbidîn, Muhammed Emîn Alâuddîn b. Ömer. Reddü'l-muhtâr ale'dDürri'l-muhtâr. 6 Cilt. Beyrut: Dârü'l-Fikr, 1412/1992.

İbnü'l-Arabî, Ebû Bekr Muhammed b. Abdillâh el-Meâfirî. el-Mesâlik fi şerhi Muvațta 'i Mâlik. thk. Muhammed b. el-Süleymânî vd.. 8 Cilt. b. y.: Dârü'l-Arabi'l-İslâmî, 1428/2007.

İbn Fâris, Ebu'l-Hüseyn b. Zekeriyyâ er-Râzî. Mu'cemü makâyisi'l-luğa. thk. Muhammed Abdüsselâm Hârûn. 6 Cilt. Beyrut: Darü'l-Fikr, 1399/1979. 
M. BAYAR / The Rights of the Dead Over the Alives in Islamic Fiqh I 297

İbn Hacer, Ahmed b. Muhammed b. Alî el-Heytemî. Tuhfetü'l-muhtâc fî şerhi'l-Minhâc. thk. Mustafâ Muhammed. 10 Cilt. Beyrut: Dârü İhyâi't-Türasi'l-Arabî, 1357/1983.

İbn Kudâme, Ebû Muhammed Muvaffakuddîn Abdullâh b. Ahmed b. Muhammed. el-Mŭgnî. 10 Cilt. Kahire: Mektebetü'l-Kâhire, 1388/1968.

İbn Nüceym, Zeynüddîn b. İbrâhîm b. Muhammed el-Misrî. el-Bahrü'rrâik şerhu Kenzi'd-dekâik (Tekmile ile birlikte). 8 Cilt. Kahire: Dârü'1Kitâbi'l-İslâmî, ts.

İbn Rüşd, Ebü'l-Velîd Muhammed b. Ahmed b. Muhammed el-Kurtubî. Bidâyetü'l-müctehid ve nihâyetü'l-mukteșld. 4 Cilt Kahire: Dârü'lHadîs,1425/2004.

İzzüddîn Ebû Muhammed Abdülazîz b. Abdisselâm es-Sülemî edDımaşkî. Kavâidü'l-ahkâm fî masâlihi'l-enâm. thk. Tâhâ Abdurraûf Sa 'd. 2 Cilt. Kahire: Mektebetü'1-Külliyyati'1-Ezheriyye, 1414/1994.

Karâfî, Ebu'l-Abbâs Şihâbuddîn Ahmed b. İdrîs. ez-Zahîre. thk. Muhammed Hacî vd.. 14 Cilt. Beyrut: Dâru'l-Garbi'l-İslâmî, 1415/1994.

Kâsânî, Alâuddîn b. Mes'ûd. Bedâi 'u's-sanâi fî̀ tertîbi'ş-şerâi'. 7 Cilt. Beyrut: Dârü'l-Kütübi'l-İlmiyye, 1406/1986.

Kaya, Eyyüp Said - Hacak, Hasan. "Zimmet". Türkiye Diyanet Vakfı İslâm Ansiklopedisi. 44/424-428. İstanbul: TDV Yayınları, 2013.

Kermî, Zeynüddîn Merî̀ b. Yûsuf b. Ebî Bekr. Delîlü't-tạlib li-neyli'lmețâlib. Ebû Kuteybe Muhammed el-Feryâbî. Riyad: Dâru'tTayyibe, 1425/2004.

Koç, Sermet - Can, Muhammed. "Ölüm Kavramı ve Ölüm Muayenesi". Klinik Değişim 22/Özel Sayı (2009), 11-22.

Mâverdî, Ebü'l-Hasen Alî b. Muhammed b. Habîb. el-Hâvi'l-kebîr. thk. Alî Muhammed Muavvız vd.. 19 Cilt. Beyrut: Dâru'l-Kütübi'l-İlmiyye, 1419/1999.

Mâzerî, Ebû Abdillah Muhammed b. Alî. Şerhu't-Telkîn. thk. Muhammed el-Muhtâr es-Selâmî. 5 Cilt. Mısır: Dârü'l-Garbi'l-İslâmî, 2008.

Merdâvî, Ebü'l-Hasen Alâüddîn Alî b. Süleymân b. Ahmed. el-İnsâf fî ma 'rifeti'r-râcihi mine'l-hilâf. 12 Cilt. Beyrût: Dâru İhyâi't-Turâsi'l'Arabî, ts. 
Molla Hüsrev, Muhammed b. Ferâmurz b. Alî. Dürerü'l-hükkâm fî şerhi Ġureri'l-aḥkâm. 2 Cilt. Misır: Dârü İhyâi Kütübi'l-Arabî, ts.

Müslim, Ebu'l-Hüseyn b. Haccâc el-Kuşeyrî. Sahîhu Müslim. thk. Muhammed Fuâd Abdülbâkî. 5 Cilt. Beyrut: Dârü İhyâi't-Türâsi'1Arabî, ts.

Nefrâvî, Ahmed b. Gunaym b. Sâlim. el-Fevâkihu'd-Devvânî Alâ Risâleti İbn Ebî Zeydi'l-Kayravânî. 2 Cilt. Beyrut: Dârü'l-Fikr, 1995.

Nesâ̂i, Ebû Abdurrahmân Ahmed b. Şuayb. es-Sünen 'ü'ș-șuğrâ. thk. Abdülfettâh Ebû Gudde. 9 Cilt. Haleb: Mektebü'l-Matbû'âti'lİslâmiyye, 1406/1986.

Nevevî, Ebû Zekeriyyâ Muhyiddîn Yahyâ b. Şeref. el-Mecmû' şerhü'lMühezzeb. thk. Muhammed Necib el-Mutîî. 23 Cilt. Cidde: Mektebetü'l-İrşad, ts.

Nevevî, Ebû Zekeriyyâ Muhyiddîn Yahyâ b. Şeref. Ravdatü't-tâlibîn umdetü'l-müftîn. thk. Züheyr eş-Şâvîş. 12 Cilt. Beyrut: elMektebetü'1-İslâmî, 1412/1991.

Özdemir, Merve. İslam Hukukuna Göre Beden Üzerinde Tasarruf ve Organ Nakli. Sakarya: Sakarya Üniversitesi, Sosyal Bilimler Enstitüsü, Doktora Tezi, 2017.

Râfi 'î, Ebü'l-Kâsım Abdulkerîm b. Muhammed. el-Azîz Şerhu' l-Vecîz. thk. Adil Ahmed Abdülmevcûd vd.. 13 Cilt. Beyrut. Dârü'l-Kütübi'lİlmiyye, 1417/1997.

Râzî, Zeynüddîn Muhammed b. Ebî Bekr. Muhtâru's-sıhâh. thk. Yûsuf eşŞeyh Muhammed. Beyrut: Mektebetü'l-Asriyye, 1420/1999.

Remlî, Ebû Abdillâh Şemsüddîn Muhammed b. Ahmed b. Ahmed b. Hamza. Nihâyetü'l-Muhtâc İlâ şerhi'l-Minhâc. 8 Cilt. Beyrut: Dârü'lFikr, 1404/1984.

Sa' dî, Ebû Habîb. el-Kâmûsu'l-fikhî. Dımaşk: Dârü'l-Fikr, 1408/1988.

Semerkandî, Ebû Bekr Alâüddîn Muhammed b. Ahmed b. Ebî Ahmed. Tuhfetü'l-fukahâ. 3 Cilt. Beyrut: Dârü'l-Kütübi'l-İlmiyye, 1414/1994.

Serahsî, Ebû Bekr Şemsü'l-eimme Muhammed b. Ebî Sehl Ahmed. elMebsût. 30 Cilt. Beyrut: Dârü'l-Ma'rife, ts.

Seyyid Sâbık, Fıkhü's-sünne. Beyrut: Darü'l-Kütübi'l-Arabî,1397/1977.

Şirbînî, Şemsüddîn Muhammed b. Ahmed el-Hatîb. Muğni'l-muhtâc ilâ ma`rifeti me'ânî elfâzi'l-Minhâc. 6 Cilt. Beyrut: Dârü'l-Kütübi'lİlmiyye, 1415/1994. 
M. BAYAR / The Rights of the Dead Over the Alives in Islamic Figh I 299

Tala, Murat. Ölümün Özel Haklara Etkisi. Konya: Selçuk Üniversitesi, Sosyal Bilimler Enstitüsü, Yüksek Lisans Tezi, 2006.

Turan, M. Fatih. "Fıkhî Açıdan Otopsi”. İslam Hukuku Araştırmaları Dergisi 23 (2014), 271-296.

Türk Hukuk Kurumu. Türk Hukuk Lugatı. Ankara: Başbakanlık Basımevi, 1991.

Yaman, Ahmet. "İslam Hukuku Açısından Organ Nakli ve Beyin Ölümü". Tip, Etik, Din, Sosyoloji ve Hukuk Bağlamında Organ Nakli Sorunlar ve Çözüm Önerileri Sempozyumu. Malatya: y.y., Mayıs 2014, 26-36.

Zerkâ, Mustafâ Ahmed. el-Medhal ilâ nazariyyeti'l-iltizâmi'amme fi'l-fikhı'lİslâmî. Dımaşk: Darü'l-Kalem, 1420/1999.

Zuhaylî, Vehbe b. Mustafa. el-Fıkhü'l-İslâmî ve edilletuh. 8 Cilt. Dimaşk: Dârü'l-Fikr, 2. Basım, 1405/1985. 